\title{
Review \\ Curcumin: Modulator of Key Molecular Signaling Pathways in Hormone-Independent Breast Cancer
}

\author{
Reyhaneh Farghadani *(D) and Rakesh Naidu *(D) \\ Jeffrey Cheah School of Medicine and Health Sciences, Monash University Malaysia, Jalan Lagoon Selatan, \\ Bandar Sunway 47500, Selangor, Malaysia \\ * Correspondence: reyhaneh.farghadani@monash.edu or r_farghadani@yahoo.com (R.F.); \\ rakesh.naidu@monash.edu (R.N.)
}

check for updates

Citation: Farghadani, R.; Naidu, R. Curcumin: Modulator of Key Molecular Signaling Pathways in Hormone-Independent Breast Cancer. Cancers 2021, 13, 3427. https:// doi.org/10.3390/cancers13143427

Academic Editor: Didier Picard

Received: 4 June 2021

Accepted: 30 June 2021

Published: 8 July 2021

Publisher's Note: MDPI stays neutral with regard to jurisdictional claims in published maps and institutional affiliations.

Copyright: (c) 2021 by the authors. Licensee MDPI, Basel, Switzerland. This article is an open access article distributed under the terms and conditions of the Creative Commons Attribution (CC BY) license (https:// creativecommons.org/licenses/by/ $4.0 /)$.
Simple Summary: Breast cancer remains the most commonly diagnosed cancer and the leading cause of cancer death among females worldwide. It is a highly heterogeneous disease, classified according to hormone and growth factor receptor expression. Patients with triple negative breast cancer (TNBC) (estrogen receptor-negative/progesterone receptor-negative/human epidermal growth factor receptor (HER2)-negative) and hormone-independent HER2 overexpressing subtypes still represent highly aggressive behavior, metastasis, poor prognosis, and drug resistance. Thus, new alternative anticancer agents based on the use of natural products have been receiving enormous attention. In this regard, curcumin is a promising lead in cancer drug discovery due its ability to modulate a diverse range of molecular targets and signaling pathways. The current review has emphasized the underlying mechanism of curcumin anticancer action mediated through the modulation of PI3K/Akt/mTOR, JAK/STAT, MAPK, NF-kB, p53, Wnt/ $\beta$-catenin, apoptosis, and cell cycle pathways in hormone-independent breast cancer, providing frameworks for future studies and insights to improve its efficiency in clinical practice.

Abstract: Breast cancer is the most frequently diagnosed cancer and the leading cause of cancer death among women worldwide. Despite the overall successes in breast cancer therapy, hormoneindependent HER2 negative breast cancer, also known as triple negative breast cancer (TNBC), lacking estrogens and progesterone receptors and with an excessive expression of human epidermal growth factor receptor 2 (HER2), along with the hormone-independent HER2 positive subtype, still remain major challenges in breast cancer treatment. Due to their poor prognoses, aggressive phenotype, and highly metastasis features, new alternative therapies have become an urgent clinical need. One of the most noteworthy phytochemicals, curcumin, has attracted enormous attention as a promising drug candidate in breast cancer prevention and treatment due to its multi-targeting effect. Curcumin interrupts major stages of tumorigenesis including cell proliferation, survival, angiogenesis, and metastasis in hormone-independent breast cancer through the modulation of multiple signaling pathways. The current review has highlighted the anticancer activity of curcumin in hormone-independent breast cancer via focusing on its impact on key signaling pathways including the PI3K/Akt/mTOR pathway, JAK/STAT pathway, MAPK pathway, NF-kB pathway, p53 pathway, and $\mathrm{Wnt} / \beta$-catenin, as well as apoptotic and cell cycle pathways. Besides, its therapeutic implications in clinical trials are here presented.

Keywords: triple negative; HER2; hormone-independent; breast cancer; curcumin; signaling pathway; clinical trial; polyphenol; phytochemical; chemotherapy and chemoprevention

\section{Introduction}

Cancer as the complex disease is a major cause of morbidity and mortality around the world, with 9.9 million deaths in 2020, and has been considered as the world's biggest killer by the age of 70 years in most countries in 2019. The world cancer burden is still 
increasing, with an estimated occurrence of 28.4 million new cancer cases in 2040, which is an increase of about $47 \%$ compared to 2020 globally [1,2]. Among the various types of cancer, breast cancer remained the most frequently occurring cancer among women worldwide, with 2,261,419 newly diagnosed cases in 2020, accounting for 1 in 4 cancer cases, and has now surpassed lung cancer in global cancer incidence. Besides, female breast cancer ranks first in terms of mortality, with 684,996 deaths in 2020 accounting for 1 in 6 cancer deaths globally [2]. Although the incidence rates of breast cancer vary worldwide and remain much higher in Australia and New Zealand (95.5 per 100,000), rapid rises have been observed in Africa and Asia. There has been a historically low incidence in Asian countries such as Japan and Korea in recent years [3-5].

Breast cancer is well known as a genetically and clinically heterogeneous disorder encompassing numerous subtypes, with distinct histopathological patterns and molecular characteristics resulting in various responses to therapies and clinical outcomes [6,7]. In this respect, the differential expression of the growth factor and hormonal receptors (HR) including the presence or absence of the progesterone receptor (PR) and estrogen receptor (ER), or the amplification/overexpression of the human epidermal growth factor receptor-2 oncogene (HER2), have been considered as the chief determinants of these subtypes [8,9].

Approximately, two-thirds of breast cancers are ER+ and/or PR+, which are hormonesensitive and responsive to endocrine therapy with, aromatase inhibitors and selective ER modulators [10,11]. However, the overexpression of HER2, a tyrosine kinase receptor mediating cell proliferation and survival, occurs in about $15-30 \%$ of breast cancer. HER2positivity has been more frequently reported in HR- compared to HR+ cancers correlated with an aggressive disorder and poor prognosis [12-14]. Although HER2-targeted therapies have dramatically improved the overall survival among hormone-independent HER2+ patients, drugs-related side effects are yet major obstacles ahead $[12,15,16]$. Besides, triple negative breast cancer (TNBC) represents a specific subtype accounting for approximately $15-20 \%$ of breast cancers, which is clinically negative for the expression of ER and PR, and lacks HER2 overexpression (ER-, PR-, HER2-). TNBC has a highly aggressive clinical behavior, prone to earlier relapses and often metastasis to the brain and lungs correlated with poorer overall survival compared with other subtypes. This subgroup is also difficult to treat and fails to respond to hormonal therapies or those targeting the HER2 receptors [17-19].

Therefore, despite the overall successes in breast cancer therapy, challenges to managing and treating hormone-independent breast cancers (HER2+ or HER2-) still remain. Hence, in addition to the conventional medicine, it is urgent to develop more effective agent without side effects. In this regard, chemical entities present in plants are now becoming a significant option in cancer drug discovery. One of the most noteworthy of phytochemicals, curcumin, has attracted enormous attention as a promising drug candidate in breast cancer prevention and treatment [20-23].

Curcumin is the major bioactive constituent of the turmeric spice derived from the rhizome of the plant Curcuma longa L. It has been widely used in traditional Indian medicine (Ayurveda) for the treatment of a variety of diseases for at least 4000 years [24,25]. This golden spice has also been found to exert preventive and therapeutic effects in breast cancer. The preclinical models have demonstrated the pivotal role of curcumin in breast cancer progression through regulating cell survival, proliferation, apoptosis, invasion, angiogenesis, and metastasis [26-29]. Given to its significance, the current review has highlighted diverse underlying mechanisms of anticancer activity of curcumin in hormoneindependent breast cancer mediated via its interaction with numerous signaling pathways. The key intracellular signaling networks are the PI3K/Akt/mTOR pathway, JAK/STAT pathway, MAPK pathway, NF-kB pathway, p53 pathway, and Wnt/ $\beta$-catenin pathway, as well as apoptotic and proliferation pathways. Besides, its therapeutic implications in clinical trials are here presented. In the current review, MDA-MB-231, MDA-MB-435, MDA-MB-436, MDA-MB-468, SUM159, HCC1806, HCC1937, Hs578T, EMT6 and 4T1 cell lines are categorized as hormone-independent HER2 negative breast cancer subtypes, also 
known as TNBC (ER-, PR-, HER2-), while SKBR-3 and MDA-MB-453 are categorized as hormone-independent HER2 positive breast cancer (ER-, PR-, HER2+) subtypes.

\section{Curcumin: Impacts on Multiple Cellular Signaling Pathways in Hormone-Independent Breast Cancer}

Cell signal transductions are the central processes playing a critical role in cancer progression and development. Existing evidence strongly implies that curcumin interrupts major stages of tumorigenesis, including cell proliferation, survival, angiogenesis, and metastasis in hormone-independent breast cancer through its modulatory effect on the functions of multiple signaling pathways discussed below.

\subsection{The PI3K/Akt/mTOR Pathway}

The phosphatidylinositol-3-kinase (PI3K)/the protein kinase B (PKB or AKT)/the mammalian target of the rapamycin (mTOR) pathway (PAM pathway) involves an intricate signaling cascade linking receptor tyrosine kinase (RTK) to the regulation of cell growth and survival, as well as angiogenesis and metabolism. It is activated by the stimulation of RTK followed by PI3k recruitment and its phosphorylation. After being activated, PI3k triggers the activation of a key signaling kinase AKT, which in turn regulates several downstream effector molecules like mTOR, promoting protein and lipid synthesis and ultimately cell growth. In addition, the activated AKT may inhibit apoptosis and promotes cell survival via the subsequent modulation of various target molecules such as the Bcl-2 family of proteins [30-32].

The PAM pathway is the most frequently altered pathway in breast cancer, approximately $70 \%$ of cases, and is often activated in the TNBC involved in chemoresistance and survival [32-35]. Besides, the constitutive activation of the PAM pathway is a potential mechanism of resistance to anti-HER2 therapies [36]. Its oncogenic activation may occur through various mechanisms. The overexpression of the upstream regulator epidermal growth factor receptor, the loss of negative regulators such as proline-rich inositol polyphosphatase and phosphatase and tensin homolog (PTEN), in addition to mutations of the PI3K gene, may result in an upregulated PAM signaling pathway in HR- breast cancer [37-39]. Activating the PIK3CA gene mutation is the most common alteration in breast cancer with different frequency among various subtypes identified more than $70 \%$ in luminal tumors, $39 \%$ in hormone-independent HER2+, and approximately $9 \%$ in TNBC [32,40]. However, in TNBC, the loss of PTEN or INPP4B mainly contributes to the dysfunction of the PAM pathway correlated with increased levels of phosphorylated Akt. Additionally, AKT and mTOR mutations occur relatively rarely in TNBC compared to the hormone-independent HER2+ type $[33,40]$. Accordingly, given its critical role in tumorigenesis, the PAM pathway represents an attractive target for novel therapies.

Curcumin has been proven to interfere with the PAM pathway through targeting various signaling molecules, shown in Figure 1, which may facilitate the inhibition of cellular growth, invasion, and metastasis in HR- breast cancer. It has been found that curcumin treatment dramatically downregulated the expression of AKT in a dose- and time-dependent manner in MDA-MB-231 cells, resulting in the suppression of the PAM pathway and, subsequently, the inhibition of cellular proliferation and migrations in TNBC [41]. Curcumin post-translationally regulated Akt protein levels via its degradation. This modification was mediated through the stimulatory effect of curcumin on AMPK activity and the subsequent activation of the autophagy-dependent degradation pathway. [41]. Curcumin has the potential to reverse the epithelial-mesenchymal transition (EMT) mechanism by influencing the expression of EMT-related genes in the TNBC cell line. Curcumin treatment downregulated AXL, $\beta$-catenin, slug, and vimentin in MDA-MB-231 cells. AXL triggers the PAM pathway through promoting AKT activation, which in turn targets downstream epithelial and mesenchymal regulatory markers leading to tumor cell invasion. Therefore, curcumin may inhibit the invasive ability of TNBC cells through AKT-mediated EMT inhibition [42-44]. In addition, it was found that the acquisition of a mesenchymal phenotype in TNBC occurred following doxorubicin treatment is mediated 
through the PAM pathway. Interestingly, curcumin has been demonstrated to suppress doxorubicin-induced EMT in MDA-MB-231 cells through a reduced expression of $\mathrm{p}-\mathrm{AKT}$, p-GSK $3 \beta$, and $\beta$-catenin, and the consequent inhibition of the PAM pathway [45].

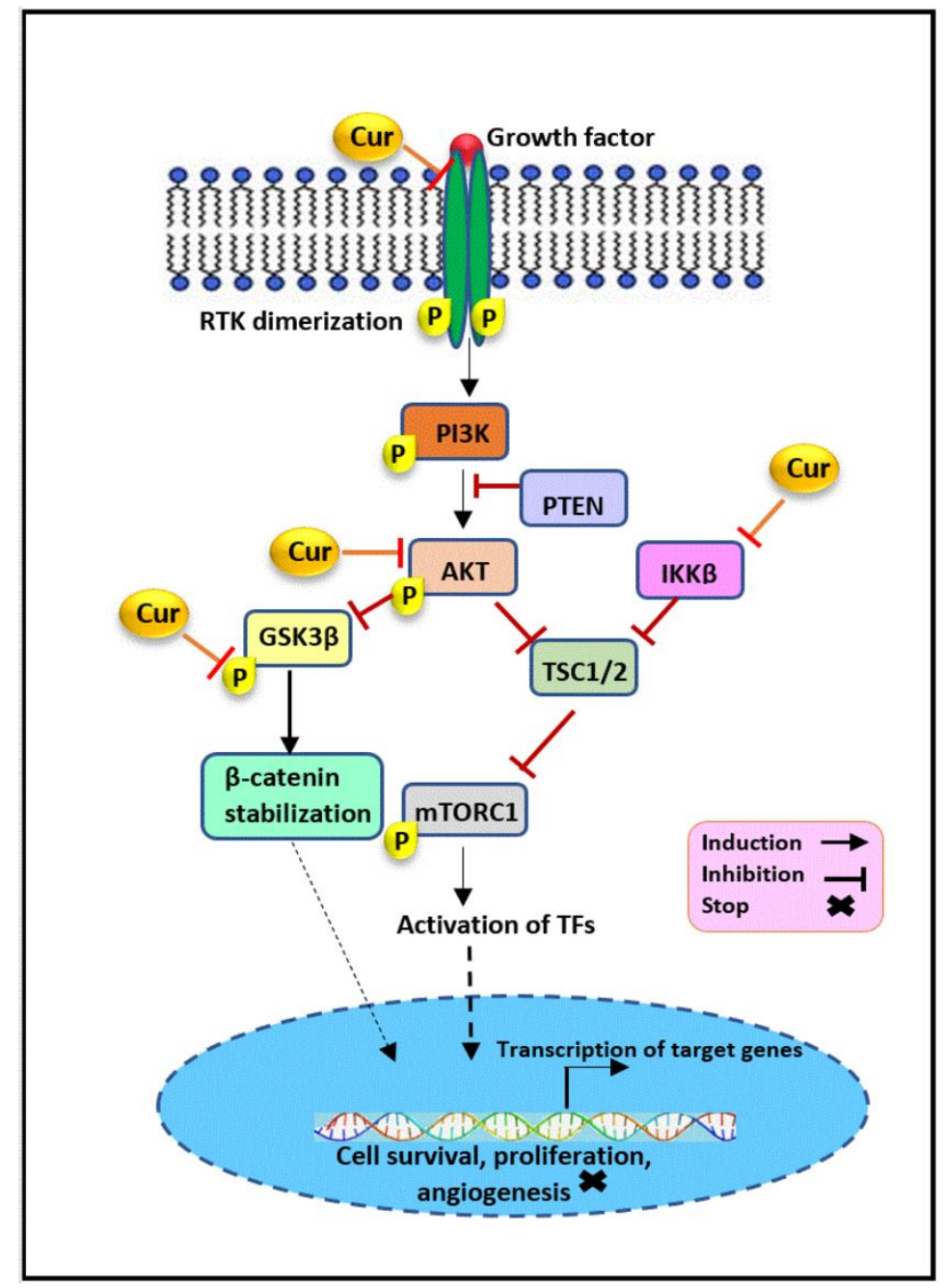

Figure 1. The modulatory effect of curcumin on the PI3K/Akt/mTOR pathway. Curcumin inhibits the PAM signaling pathway through the regulation of its key components. Curcumin downregulates IKK $\beta$, AKT, GSK3 $\beta$, and HER2 expression, which may facilitate the inhibition of cellular growth, invasion, and metastasis in hormone receptor negative breast cancer. Cur: curcumin, PI3K: phosphatidylinositol-3-kinase, $\mathrm{AKT}(\mathrm{PKB})$ : protein kinase $\mathrm{B}, \mathrm{mTORC}$ : mammalian target of rapamycin complex $1, \mathrm{IKK} \beta$ : IKB kinase $\beta$, PTEN: phosphatase and tensin homolog, TSC: tuberous sclerosis complex, RTK: receptor tyrosine kinase, GSK3 $\beta$ : glycogen synthase kinase- $3 \beta$, TFs: transcription factors.

In addition, curcumin may have a modulatory effect on IKB kinase $\beta$ (IKK $\beta)$. IKK $\beta$ is an upstream kinase that plays a significant role in regulating the PAM pathway through its association with mTORC1 in MDA-MB-453. It binds directly to TSC1, a repressor of mTORC1, and, via its phosphorylation, disrupt the TSC1/TSC2 complex function and subsequently enhances mTORC1 activity, contributing to tumorigenesis. Given IKK $\beta$ 's role in hormone-independent HER2+ breast cancer and evidence showing the potential of the curcumin as a IKK $\beta$ inhibitor, curcumin may exert its PAM-mediated effect on MDA-MB-453, at least in part, in this way [46,47]. Another suggested mechanism is the downregulation of oncoprotein NEDD4, as an E3-ubiquitin ligase involved in the posttranslational modification of protein like PTEN and its degradation by curcumin. It has been found that the overexpression of NEDD4 is involved in the proliferation and migration 
of MDA-MB-231 cells. A study on breast cancer tissue has also revealed the importance of elevated NEDD4 expression in promoting breast cancer cell growth, progression, and poor prognosis $[48,49]$. NEDD4 has been demonstrated to negatively regulate the PTEN protein levels in numerous cancers, such as prostate, bladder, lung, and colon [50-52]. However, subsequent studies have shown that there is no such correlation in breast cancer, and NEDD4 promote cancer cell growth by facilitating the activation of Akt. Therefore, it is suggested that curcumin may induce NEDD4-mediated PAM suppression in HR- breast cancer in a PTEN degradation-independent manner, worthy of further investigation $[48,53]$. Besides, it was noted that curcumin suppressed the basal phosphorylation of Akt in MDAMB- 468 cells and then contributed to the significant inhibition of invasion and proliferation and enabled the occurrence of apoptosis in treated cells [54].

Previously it was also shown that treatment with curcumin reduced the cell viability and migration of SKBR-3 and MDA-MB-231 cells. In the same study, curcumin's effect on tyrosine kinase was investigated, showing a decrease of HER2 combined with a reduction of Akt phosphorylation in a time- and dose-dependent manner in the SKBR-3 cell line [55]. Similarly, another study has revealed the potential utility of curcumin in downregulating the expression of HER2 mRNA and protein in SKBR-3, representing the inhibition of the HER2-related PAM pathway [56]. Evidence also implies that curcumin treatment led to the time- and dose-dependent inhibition of AKT phosphorylation and suppressed Foxo1 and Foxo3a phosphorylation as its downstream targets in MDA-MB-231 cells [57].

\subsection{The JAK/STAT3 Pathway}

Janus kinase (JAK)/signal transducer and activator of the transcription 3 (STAT3) signaling pathway is a chain of interactions among the proteins within the cell whose role is well characterized in the immune system, cell growth, proliferation, differentiation, cell death, and hematopoiesis. Upon stimulation with various factors, such as epidermal growth factor, interferons and interleukin 6 (IL-6), the corresponding receptors get dimerized. This receptor dimerization promotes the phosphorylation of the JAK protein, their cytosolic domain, and eventually the STAT protein. Two such activated STAT3 proteins become attached with one another and form a STAT3 homodimer, which ultimately translocates into the nucleus and act as the transcription factor via interacting with enhancer or promoter regions of DNA in target genes, resulting in their transcription activation [58-60]. A considerable amount of literature from clinical and preclinical studies has extensively revealed the aberrant overactivity of the STAT3 pathway, which plays a vital role in breast cancer progression and development. This role is mediated by its impact on huge numbers of downstream targets involved in proliferation (e.g., cyclin D-1, c-myc), apoptosis (e.g., bcl-2, Bax), metastasis (e.g., MMP-2, -9, Twist), as well as chemoresistance [61-66]. Interfering with this oncogenic pathway is thus an attractive therapeutic approach.

The JAK/STAT3 signaling pathway has been demonstrated as another target of curcumin, as illustrated in Figure 2. Considerable evidence demonstrates that STAT3 is upregulated and constitutively activated in approximately $70 \%$ of breast tumors, which are mostly TNBC. The aberrant activity of STAT3 is linked to survival, stem cells self-renewal, immune evasion, angiogenesis and metastasis, multidrug resistance, and other functions in TNBC cells [67-69]. Moreover, suppressing the STAT3-mediated metabolism may inhibit the breast cancer cellular proliferation [70-72]. Furthermore, STAT3 expressions have been indicated to be correlated with HER2 amplification. Importantly, a HER2-STAT3 signaling pathway has been determined in hormone-independent HER2+ breast cancer stem cell as well [73-75]. Therefore, the blockade of STAT3 by inhibitors is considered to be a promising direction for tumorigenesis and metastasis inhibition in breast cancer, and, notably, curcumin has been reported as a potent inhibitor. 


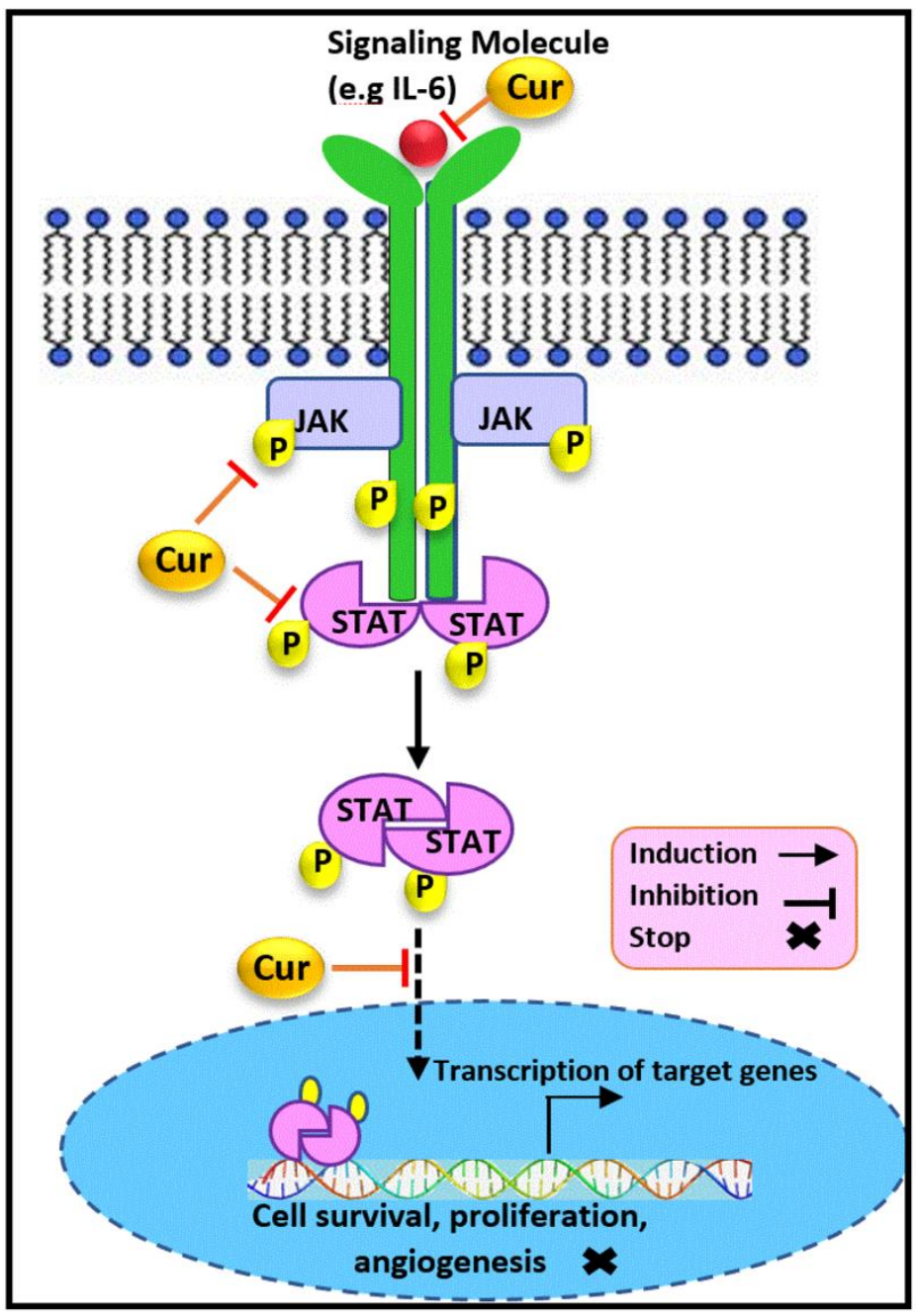

Figure 2. The modulatory effect of curcumin on the JAK/STAT3 pathway. Curcumin inhibits the JAK/STAT3 signaling pathway through the regulation of its key components. Curcumin downregulates STAT, JAK, and IL-6 expression and inhibits STAT translocation into the nucleus, which results in the suppression of cell proliferation, invasion, and metastasis in hormone receptor negative breast cancer. Cur: curcumin, JAK: janus kinase, STAT: signal transducer and activator of transcription, IL-6: interleukin-6.

Indeed, curcumin treatment exhibited potent growth suppressive activity and repressed the STAT3 phosphorylation in the MDA-MB-231 and SKBR-3. This result was further confirmed through the inhibitory effect of curcumin on the DNA binding capability of STAT3 and its transcriptional activity [76], which were in accordance with previous reports $[67,77]$. Therefore, curcumin targets STAT3 signaling by blocking STAT3 activation in vitro. Besides, 3-dimensional culture conditions of TNBC cells revealed that curcumin prevented the tumor-sphere formation and invasiveness of MDA-MB-231 cells [78]. The findings suggested that curcumin induced the inhibition of STAT3 phosphorylation and therefore inhibited its translocation into the nucleus, which resulted in a slightly reduced NFkB-STAT3 protein interaction and downregulation of CD44 as the marker of cancer stem cell phenotype. Hence, curcumin blocked STAT3-mediated signaling, which contributed to the suppression of the cancer stem cell phenotype in TNBC [78].

A further study also showed that curcumin treatment potentially reduced the active STAT3 expression, which led to a downregulation of its downstream targets and, subsequently, to the suppression of cellular proliferation, colony formation, and cell migration, along with apoptosis induction in treated MDA-MB-231 breast cancer cells [79]. Likewise, it is obvious that breast cancer cells are co-present together with normal mammary 
cells. Interestingly, it has also been reported that curcumin has the potency to inhibit the paracrine signaling stimulatory effects from TNBC, MDA-MB-231 cells, on non-cancerous mammary epithelial, MCF-10A cells, mediated by blocking the Stat 3 phosphorylation [80]. A recent study conducted on wide type $(\mathrm{Wt})$ and forced growth hormone $(\mathrm{GH})$ expressing MDA-MB-453 and MDA-MB-231 cells has demonstrated that curcumin exposure not only reduced the cell viability and exerted its anti-invasive and metastatic effect, but also caused a dose-dependent reduction in GH expression in GH-expressing breast cancer cells. Additionally, an enhanced concentration of curcumin also overcame drug resistance in those cell lines [81]. Interestingly, the findings revealed that curcumin exposure attenuated protein expression and inhibited the phosphorylation of JAK2, STAT3, STAT5, and STAT1 in $\mathrm{Wt}$ and $\mathrm{GH}+$ breast cancer cells. Concomitantly, the diminished expression of the wide range of their downstream targets, such as Ras, c-fos, c-raf, c-jun, c-myc, vimentin, snail, and $B$-catenin, has also been reported to contribute to the potent impact of curcumin on the respective treated cells [81]. Therefore, curcumin has been found to modulate GHinduced aggressiveness and suppress the JAK/STAT signaling mechanism activation in triple negative and hormone-independent HER2+ breast cancer cells.

Besides, the persistent autocrine expression of IL- 6 cytokine has been considered as an important contributor to progression, resistance, and immune suppression in TNBC. IL-6 also plays a critical role in transforming the dormant breast cancer cells into the actively growing tumor [82,83]. On the other hand, IL-6 activation has been reported to trigger the STAT3 phosphorylation and its activity [84-86]. It has been previously shown that the production of IL- 6 was significantly reduced in TNBC in vivo 4 T1 following curcumin treatment [83]. Hence, another mechanism of curcumin's modulatory effect on the STAT3 pathway has been suggested to be its impact on IL-6, which is able to turn on the initiation of the IL-6/JAK/STAT3 pathway.

\subsection{ERK/MAPK Pathway}

The mitogen-activated protein kinase (MAPK)/extracellular signal-regulated kinase (ERK) pathway, also known as the Ras-Raf-MEK-ERK pathway, is a transduction cascade transmitting an extracellular signal from mitogens like EGF into the series of signaling events which ultimately promotes cell division, cell proliferation, survival, and cell differentiation. The binding of the mitogen to the cell-surface RTK leads to its dimerization and phosphorylation, and to the recruitment of Grb2/Sos. As a consequence, Ras is activated, and the sequential phosphorylation and activation of Raf, MEK, ERK1 and ERK2 occur. Ultimately, phosphorylated ERK translocate to the nucleus and regulate the transcription of a variety of genes involved in stimulating growth and proliferation [87-89]. Besides, c-Jun N-terminal kinas (JNK) and P38MAPK, also known as stress-responsive MAPKs, are the other two MAP kinase pathways functioning in humans which are involved in inflammation, cell growth, and differentiation, as well as apoptosis [87,90]. An altered MAPK signaling pathway plays a vital role in breast cancer progression and development. MAP kinases are significantly correlated with invasion, metastasis, chemoresistance, and poor prognosis in triple negative and hormone-independent HER2 + breast cancer [91-94]. Thereby, the kinase components of these MAPK pathways have been investigated as putative targets by kinase inhibitors for breast cancer therapy.

Transforming growth factor beta 1 (TGF- $\beta 1$ ) has been found to be highly associated with cancer invasion and metastasis in late-stage breast cancer. In addition to TGF- $\beta / \mathrm{Smad}$ signaling pathway, TGF- $\beta 1$ can also trigger tumor growth and regulate cell migration and invasion via Smad-independent mechanisms through the MAP kinase pathway activation [95-97]. It was reported that nontoxic doses of curcumin exposure $(\leq 10 \mu \mathrm{M})$ resulted in the suppression of ERK1/2 and p38MAPK phosphorylation, stimulated by TGF- $\beta 1$ in a concentration- and time-dependent manner in MDA-MB-231 cells. Besides, the downregulation of TGF- $\beta 2$ expression was also found to follow curcumin treatment. Therefore, curcumin exerts its anti-invasion and migratory effect through the inhibition of TGF- $\beta 1 /$ MAPK pathway-mediated cell migration [98]. 
Furthermore, the overexpression of EGF, a potent mitogen, and its related receptor, EGFR, is a common feature in breast cancer, regulating the MAPK activity pathway. Enhanced EGFR expression is involved in the progression of tumors to hormone independence [99]. In this regard, curcumin was found to inhibit the phosphorylation of EGFR and ERK1/2 triggered by EGF, and to suppress the ERK activity in the MDA-MB-468 cells [54]. A significant inhibition of JNK, another MAPK, has also been reported following curcumin treatment, correlated with the inhibition of its upstream activator, MKK4. Subsequently, the same study revealed the downregulation of the level of nuclear c-fos and c-jun expressions as the downstream target of the ERK and JNK pathways, in MDA-MB-468 cells [54]. Another study also reported the lower expression levels of phosphorylated ERK1/2 and EGFR in curcumin-treated MDA-MB-468 cells. The findings revealed that curcumin prevented cellular proliferation and triggered apoptosis occurrence mediated by the inhibition of the EGFR/ERK pathway in TNBC cells [29]. Moreover, the incubation of the MDA-MB-231 cells with curcumin led to the reorganization of the fatty acid profile of the breast cancer cell membrane, accompanied by the modulation of p-P44/42 MAPK, ERK1/2, and EGFR expression. An increase in the stearic acid level along with the reduction of arachidonic acids, omega- 6 linoleic, and omega-3 have been reported as the membrane remodeling in TNBC cells following curcumin treatment [100].

As shown in Figure 3, MAPK signaling pathways not only promote cellular proliferation and survival, but can also mediate cell death depending upon the cell types and stimuli [101,102]. In this regard, several lines of evidence illustrated that curcumin, under certain circumstances, induces cancer cell death through MAPK activation. The published literature has demonstrated that the upregulation of the enhancer of zeste homolog 2 (EZH2), involved in cell cycle regulation, is correlated with tumor invasiveness and aggressive clinical behavior as well as the poor prognosis of breast cancers [103]. It was found that curcumin diminished EZH2 expression via the phosphorylation and activation of ERK, JNK, and p38 in MDA-MB-435 cells [104]. Similarly, curcumin-mediated apoptosis and autophagy have been detected through the increased activity of ERK, JNK, and Beclin1 in treated MDA-MB-231 [105]. The subsequent study on MDA-MB-231 and Hs578T has demonstrated that curcumin suppresses their proliferation, migratory potential, and induced cell cycle arrest and apoptotic cell death. The immunohistochemistry of clinical tissue specimens demonstrated the curcumin-induced attenuation of ki-67 and proliferation-associated nuclear antigen (PCNA), in the respective tumor tissues. The findings also represented an increase in phosphorylated JNK expression and, subsequently JNK pathway activation, which was associated with enhanced ROS generation. In agreement with analysis, curcumin was also found to prevent tumor growth and metastasis in a MDA-MB-231 xenograft mouse model. Therefore, the anticancer activity of curcumin is meditated via the ROS/JNK signaling pathway [106]. Although reports revealed that the growth inhibition of SKBR-3 cells induced by curcumin treatment was not associated with the suppression of MAPK P38 and ERK expression or phosphorylation [107,108], another study demonstrated that curcumin treatment on SKBR-3 cells resulted in the inhibition of ERK phosphorylation and was also able to sensitize hormone-independent HER2+ cells to TNF-related apoptosis inducing ligand (TRAIL) [109]. Furthermore, the increased phosphorylation of JNK found in curcumin-treated SKBR-3 cells led to the induction of JNK-dependent apoptosis [108]. 


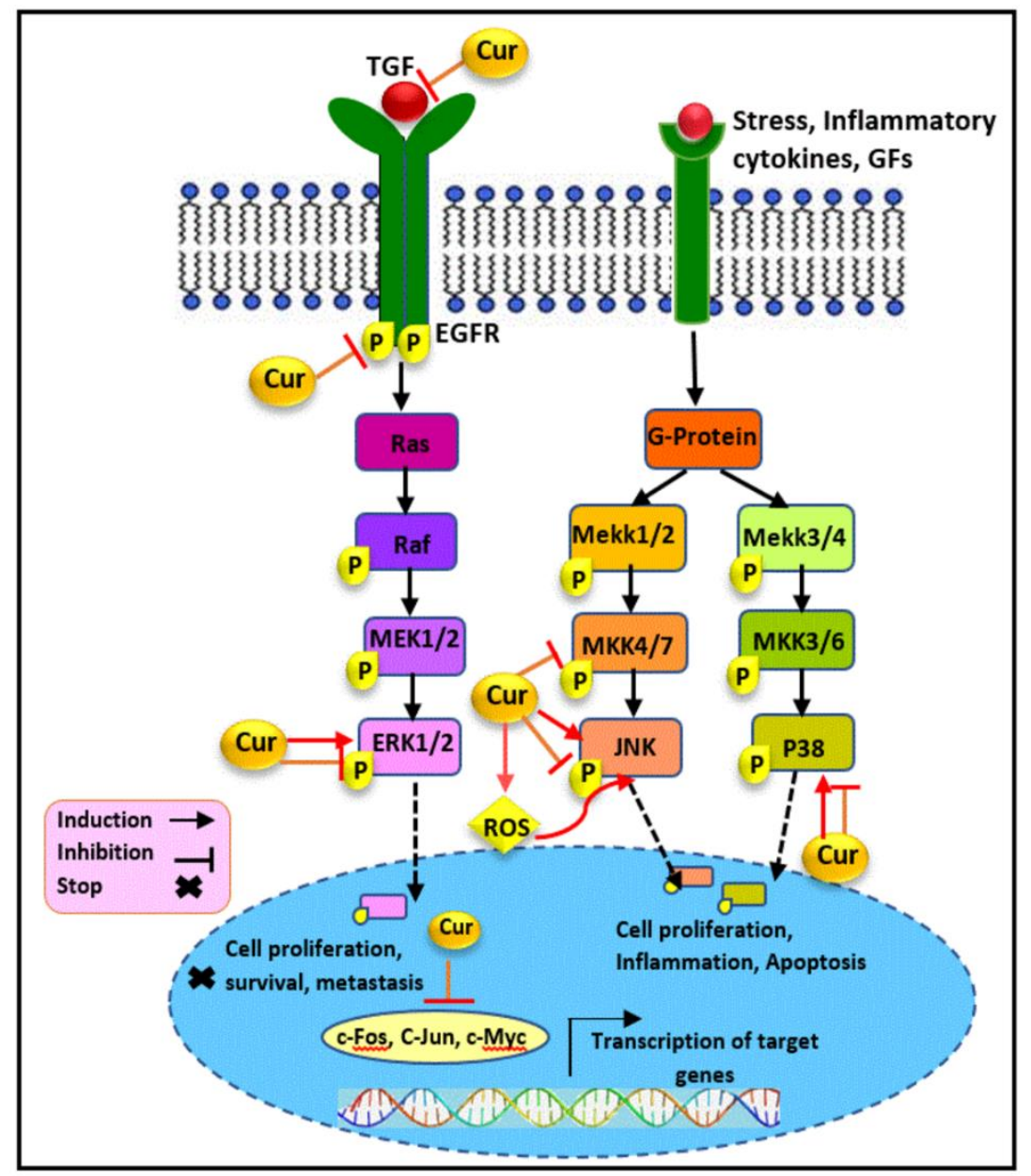

Figure 3. The modulatory effect of curcumin on the MAPK pathway. Curcumin exerts its anticancer activity through the modulation of key components involved in the MAPK signaling pathway. Curcumin targets TGF, EGFR, ERK1/2, MKK4/7, JNK, and P38 molecules and downregulates the expression level of nuclear c-Myc, c-Fos, and c-Jun as the downstream targets of the MAPK pathway, which results in the inhibition of cellular proliferation and migration as well as apoptosis induction in hormone receptor negative breast cancer. Cur: curcumin, G-protein: guanine nucleotide-binding protein, TGF: transforming growth factor, GFs: growth factors, EGFR: epidermal growth factor receptor, Raf: rapidly accelerated fibrosarcoma, MAPK: mitogen-activated protein kinase, ERK: extracellular signal-regulated kinase, MEK: MAPK/ERK kinase, Mekk: Mek kinase, MKK: MAPK kinase, JNK: c-Jun N-terminal kinases.

\subsection{NF-кB Pathway}

The nuclear factor-kappa B (NF-kB) pathway plays a critical role in promoting cell survival, inflammation, differentiation, and cell growth [110]. As shown in Figure 4, it is stimulated upon the binding of the signaling molecules, e.g., TNF- $\alpha$ or cytokines, to their corresponding receptors at the surface of the cell membrane, leading to the receptor conformational changes and the subsequent recruitment, phosphorylation, and activation of the inhibitor of kappa B kinase (IKK). NF-kB is a heterodimer complex protein, e.g., RelA (p65) and p50, rather than a single protein, presenting an inactive form associated with a group of inhibitory proteins known as inhibitors of NF-kB (IKB) in cytosol. Other members of the NF- $\mathrm{kB}$ transcriptional factor family are NF- $\mathrm{kB} 1$ (p50), NF- $\mathrm{kB} 2$ (p52), RelB, and c-Rel. Activated IKK, in turn, leads to the phosphorylation of IKB, which results in provoking I $\mathrm{K}$ polyubiquitination and its subsequent proteasome-mediated degradation. This causes NF- $\mathrm{KB}$ dissociation and its translocation to the nucleus, where it binds, as the transcriptional factor, as dimer in enhancers and promoters of downstream targets 
such as pro-inflammatory, anti-apoptotic, and cytokine-related genes to regulate their transcription, and hence numerous critical cellular process. Besides, other receptors of the TNFR superfamily such as LT $\beta R$, BAFFR, TNFR2, CD40L, and receptor tyrosine kinases such as EGFR and the AKT protein may also stimulate the activation of the NF- $\mathrm{kB}$ pathway in addition to the canonical activation [110-112].

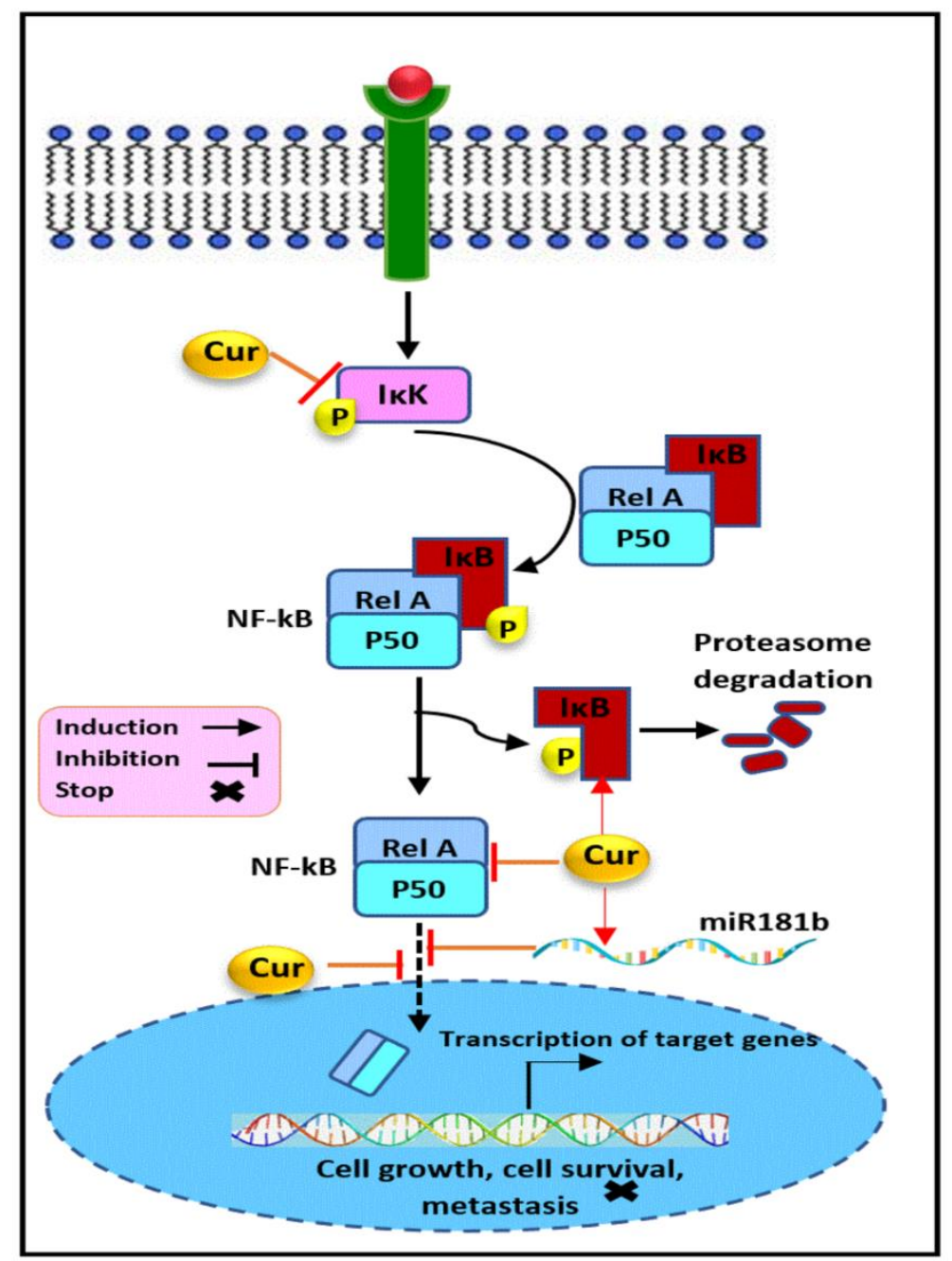

Figure 4. The modulatory effect of curcumin on the NF- $\kappa B$ pathway. Curcumin inhibits the NF- $\kappa B$ signaling pathway through the regulation of its key components. Curcumin upregulates IkB and miR181b expression and downregulates NF- $\mathrm{KB}$ and IKK, and suppresses the NF- $\mathrm{KB}$ translocation into the nucleus, which results in the inhibition of cellular proliferation, survival, metastasis, and angiogenesis in hormone receptor negative breast cancer. Cur: curcumin, IKK: inhibitor of kappa B

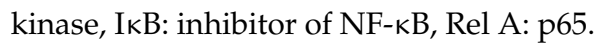

There is increasing evidence that the NF-KB pathway is constitutively activated and is a frequent characteristic in TNBC and hormone-independent HER2+ subtypes mediated through overexpression of EGFR, HER2, and NF-KB subunits including p50, c-Rel, and p65. Its aberrant activation has been strongly implicated in breast cancer pathogenesis and prognosis and facilitates the development of hormone-independent invasiveness and metastasis, angiogenesis, as well as chemo- and radio-resistance [113-116]. This evidence cooperatively highlights the urgency and significance of targeting the NF- $\mathrm{KB}$ pathway for breast cancer prevention and therapy.

Curcumin was found to induce the inhibitory action on NF-kB activation in SUM159, and MDA-MB-231, accompanied by a decrease in its target expression, including IAP-1 and surviving as anti-apoptotic factors. These findings show that the anti-invasion ability 
of curcumin might be mediated through MDA-9/Syntenin-mediated NF- $\mathrm{kB}$ regulation in treated TNBC cells [112]. Another study demonstrated the inhibitory activity of curcumin through the suppression of NF- $\mathrm{KB}$ p50 gene expression in 4T1 TNBC cells [117]. Besides, the attenuation of nuclear and cytoplasmic NF- $\mathrm{kB}$ p 65 protein expression and the subsequent modulation of the NF-kB-inducing genes, including cyclin D1, CDK4 and MMP-1, P21, were indicated as the mechanism basis for the anti-proliferative and anti-invasive properties of curcumin against MDA-MB-231 [118].

Besides, several lines of evidence have identified curcumin as a potent chemosensitizer through the regulation of the NF-KB pathway. It was shown that curcumin suppressed paclitaxel-activated NF- $\mathrm{kB}$ in in MDA-MB-435. This effect was mediated through the hindrance of IKK activation, its phosphorylation, and its degradation. The same study also revealed the apoptosis induction and decline in expression of anti-apoptotic (XIAP, IAP-1, IAP-2, Bcl-2, and Bcl-xL), proliferative (COX-2, c-Myc, and cyclin D1), and metastatic proteins (VEGF, MMP-9, and ICAM-1) in response to curcumin treatment. In support of these observations, an in vivo experiment confirmed the role of the curcumin -mediated NF- $\mathrm{kB}$ inhibition in preventing breast cancer metastasis in a xenograft mice model [119]. The other study also revealed the beneficial role of curcumin in decreasing the chemoresistance to gemcitabine through the blockage of NF- $\mathrm{kB}$ activity, and therefore the enhancement of their anticancer effect against MDA-MB-231 cells [120]. Similarly, in vitro and in vivo results obtained from a former study indicated that the sensitization of curcumin-treated breast cancer cells to paclitaxel and cyclophosphamide was mediated through the inhibition of NF- $\mathrm{KB}$ (p50 and p65), protein kinase C (PKC), histone deacetylase (HDAC), and telomerase activity in MDA-MB-231 cells and a breast cancer mouse model [121]. In line with these results, curcumin potentiates 5-fluorouracil-triggered toxicity in MDA-MB-231 cells through the thymidylate synthase-dependent downregulation of NF- $\mathrm{kB}$, IKK phosphorylation, and $\mathrm{IkB} \alpha$ degradation [122].

Another study provides evidence that curcumin reduces the expression of the p65 subunit of NF- $\mathrm{KB}$ in TNBC cells accompanied by the marked downregulation of FABP5, PPAR $\beta / \delta$, and eventually VEGF-A and PDK1 as the downstream target genes involved in cell proliferation, survival, and angiogenesis. The findings also revealed curcumin's capability to reverse the resistance of MDA-MB-231 and MD-MB-468 to retinoic acid and inhibit cancer cell growth by targeting and suppressing the NF- $\mathrm{KB}$-mediated FABP5/PPAR $\beta / \delta$ pathway [123]. It has been reported earlier that curcumin blocked the lipopolysaccharideinduced EMT procedures through the modulation of the expression of motility and invasiveness marker, e.g., vimentin and E-cadherin, in MDA-MB-231 breast cancer cells. These effects were triggered through the downregulation of NF- $\mathrm{kB}$ p 65 and the consequent repression of snail protein, a direct downstream transcription factor. Curcumin reversed cellular EMT characteristics through the inhibition of NF-KB-Snail signaling activation [124]. Likewise, another report has also demonstrated that a mild curcumin treatment exerts a disruptive impact on the adhesion and rolling behavior of SKBR-3, MDA-MB-231, and MDA-MB-468 cells and decreases the metastatic potential of circulating tumor cells most likely via acting on the NF- $\mathrm{kB}$ pathway [125]. An in vivo TNBC mouse model also indicated the inhibitory role of curcumin on tumor growth and angiogenesis. In breast tumor tissues of the curcumin-treated group, a significant suppression of NF- $\mathrm{KB}$ p 65 and a deregulation of NF-kB-related genes expression, cyclin D1, and PECAM-1 were detected [126].

Furthermore, the anti-metastatic effects of curcumin in MDA-MB-231 breast cancer cells was correlated with the reduction of inflammatory cytokines CXCL1 and CXCL2 mRNAs and proteins, which are both tightly related to metastases. The underlying mechanism involved the regulation of NF-KB p65 and IkBa expression in treated breast cancer cells [127]. In line with these findings, mechanistic studies conducted on MDA-MB-231 cells and several primary human breast cancers have revealed the miR181b upregulation involved in the curcumin-induced, downregulatory effect on CXCL1 and -2, which mediated its anti-metastatic potential [128]. miR181b is also a potent regulator of NF-kB signaling by targeting importin- $\alpha 3$, essential for the translocation of NF- $\mathrm{BB}$ to the nucleus 
and NF- $\mathrm{KB}$ inhibition [129]. Besides, the modulation of miR181b triggered by curcumin has a functional impact on tumor cell proliferation, invasion, and apoptosis. Additionally, the upregulation of miR181b in metastatic breast cancer cells was found to suppress metastasis development in an in vivo mice model [128].

\subsection{P53 Pathway}

P53 is a tumor suppressor and transcription regulator forming a homo-tetramer to induce the transcription of almost 500 target genes that are responsible for various cellular mechanisms, mainly DNA repair and cell cycle arrest, as well as apoptotic cell death. P53 is activated in response to diverse forms of stimuli such as hypoxia, DNA damage, and oncogene activation ultraviolet light. It is known as the genome guardian due to protecting and maintaining the genome's integrity and stability via triggering severely DNA-damaged cells to death. Under normal conditions, p53 is a short-lived protein where p53 expression is precisely controlled through an autoregulatory feedback loop in which murine double minute 2 (MDM2), as the negative regulator, destabilizes p53 [130-132].

P53 may promote apoptosis through a transcription-independent and -dependent mechanism which is regulated by diverse environmental factors, signals, and cell types. Within the nucleus, the transcription-dependent mechanism is mediated through the interaction of p53 with basal transcriptional machinery components and the enhancement of the expression of genes such as Bax, Noxa, and Puma. However, in the mitochondria, its non-transcriptional modes of action are chiefly mediated through its molecular interaction with anti- (Bcl-2 and Bcl-XL) and pro-apoptotic (Bak and Bax) members of the Bcl-2 family. Therefore, any loss in p53 function may contribute to tumor growth and cancer development correlated with a deficiency in the cell cycle checkpoint, instability of genome, cellular immortalization, and irregular cell survival and proliferation [132,133].

The TP53 gene, a tumor suppressor, is the most common mutated gene in breast cancer and has been reported to be more frequently altered in hormone-independent HER2+ $(72 \%)$ and TNBC $(80 \%)$ compared to the luminal A (12\%) and B (29\%) subtypes of breast cancer. There is significant evidence implying that mutated nonfunctional p53 is involved in tumorigenesis and progression and also associated with worse clinical outcomes, low survival rate, prognosis, and chemoresistance in breast cancer patients [134-137]. Therefore, anticancer agents with an ability to reactivate or boost the p53 pathway have been considered as promising drug candidates in breast cancer therapy.

The impacts of curcumin as a p53 regulator in hormone-independent breast cancer and the involvement of the fundamental molecular mechanism of this regulation (Figure 5) have been widely investigated. It has been reported that curcumin upregulates p53 expression and regulates MDA-MB-231 proliferation and apoptosis [126,138]. An in vivo study also confirmed the upregulation of p53 and the reduction of Ki67 protein levels as the underlying mechanism of suppression of breast tumor growth in curcumin-treated mice groups [139]. Moreover, curcumin treatment upregulated p53 expression and induced caspase-dependent apoptosis in SKBR-3 and MDA-MB-231. These effects were accompanied by the upregulation of Bax and Bid and the downregulation of $\mathrm{Bcl}-2$ and Bcl-xL in treated cells [140-142]. An additional study reported that the ROS-triggered DNA damage in curcumin-treated MDA-MB-231 cells resulted in p38-MAPK-mediated p53 expression. These effects were accompanied by the regulation of Bax, Bcl-2, p16, and p21 expression, which eventually led to apoptosis induction and cell cycle arrest [143]. In contrast, it has been reported that curcumin treatment decreases the expression level of p53 and phosphorylated p53 (S392, S15, S392) in MDA-MB-231, SKBR3 and EMT6 cells, representing the induction of p53- independent apoptosis in treated cells $[108,144-147]$. Moreover, it has been documented that Notch1 overexpression is correlated with a highly expressed mutant p53 (R280K) in MDA-MB-231 cells, in which mutant p53 acts as its transcriptional activator. This study on TNBC cells inferred that curcumin treatment led to apoptosis induction accompanied by a declined expression of mutant p53, Notch1, and Hes1 as its downstream target. The researchers concluded that the occurrence of cellular 
apoptosis was modulated by the inhibition of the mutant p53-Notch1 signaling axis following the exposure of the cancer cells to curcumin [148,149]. Likewise, another study also indicated curcumin-induced apoptosis. Additionally, the significance of curcumin in the p53 stability regulation of MDA-MB-231 cells was determined where $20 \mu \mathrm{M}$ curcumin treatment enhances the half-life of the P53 protein in TNBC cells. This effect was also demonstrated, along with the increased level of NQO1, which might play an important role in p53 stabilization [150].

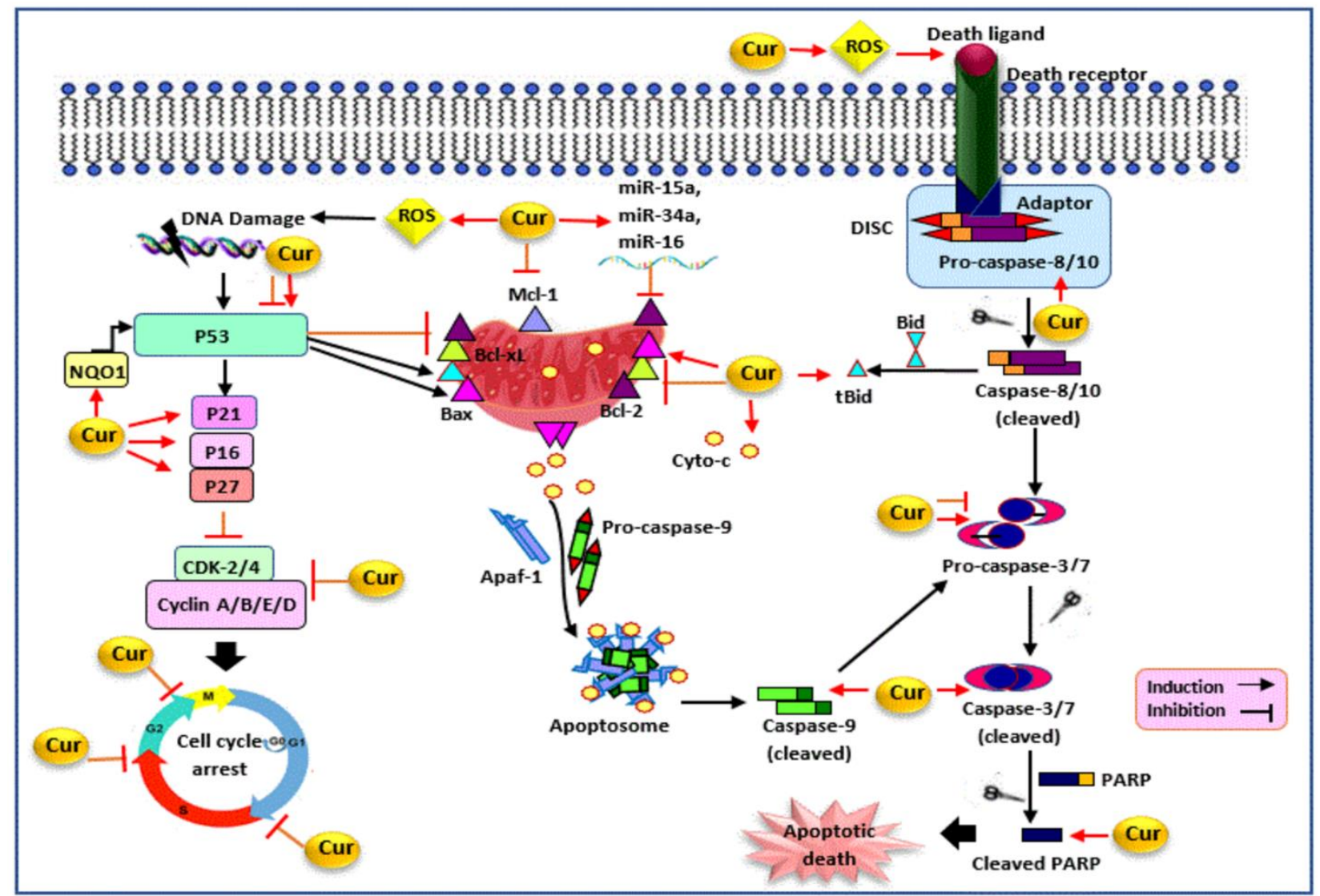

Figure 5. The modulatory effect of curcumin on p53, cell cycle, and apoptosis pathways. Curcumin inhibits cell cycle progression and induces apoptosis by targeting various molecules. Curcumin triggers ROS generation and alters the expression level of caspases (caspase-3/7, 8, 9), PARP, Bcl-2 family proteins (Mcl-1, Bcl-xL, Bid, Bax, Bcl-2), cytochrome-c, and miRNAs (miR-34a, miR-15a, miR-16), which results in apoptotic cell death in hormone receptor negative breast cancer. Curcumin also modulates P53 expression, upregulates CDKI (P21, P27, P16), and downregulates cyclins (cyclin A, B, E, D) and CDKs (CDK-2, -4), which results in cell cycle arrest in hormone receptor negative breast cancer. Cur: curcumin, DISC: death-inducing signaling complex, Bcl-2: B-cell lymphoma 2, Bid: BH3 interacting-domain death agonist, tBid: truncated Bid, Bax: Bcl-2 associated X protein, Bcl-xL: B-cell lymphoma-extra large, Mcl-1: myeloid cell leukemia 1, APAF-1: apoptotic protease activating factor-1, Cyto-c: cytochrome c, PARP: poly (ADP-ribose) polymerase, ROS: reactive oxygen species, CDK: cyclin-dependent kinase, NQO1: NAD $(\mathrm{P}) \mathrm{H}$ dehydrogenase (quinone 1).

\subsection{Wnt/B-Catenin Signaling Pathway}

Signaling by the secreted glycolipoprotein factors of the Wnt family via $\beta$-catenin, as the transcription co-activator, regulates multiple developmental processes during embryogenesis and adult homeostasis through its critical role in cell growth, differentiation, and cellular metabolism $[151,152]$. Once the Wnt signaling molecule presents itself, it binds to a Frizzled receptor and triggers the activation of the co-receptor LRP, leading to a transfer of the biological signal to a Disheveled (Dvl) protein within the cytoplasm. The activated Dvl protein then prevents the hydrolysis of $\beta$-catenin by a destructive multiprotein complex composed of several proteins, such as GSK3, APC, Axin, and CK1. As a result, $\beta$-catenin 
remains stable inside the cytosol. Accordingly, $\beta$-catenin, as the core component of this pathway, accumulates, migrates to the nucleus, and displaces the transcriptional repressor Groucho protein through the formation of the $\beta$-catenin/TCF/LEF transcriptional complex. Eventually, the transcription of Wnt-responsive genes such as slug, cyclin D1, VEGF, c-myc, and MMPs will be initiated. However, in the absence of extracellular Wnts, the $\beta$-catenin destruction complex promotes the phosphorylation, ubiquitinylation, and degradation of $\beta$-catenin in proteasome. Therefore, this pathway is maintained in an off state $[153,154]$.

The aberrant Wnt/ $\beta$-catenin signaling network, through altered functions or levels of its components, is a key driver of breast cancer progression, phenotype shaping, and recurrence $[153,155]$. Dysregulated Wnt/ $\beta$-catenin signaling, as a characteristic of TNBC, correlated with the tumorigenesis, TNBC stem cell pluripotency, clinicopathological parameters, poor clinical outcomes, and therapeutic resistance, as well as brain and lung metastases [154,156-159]. Increasing evidence has also implicated the role of the overactivity of the Wnt/ $\beta$-catenin pathway in the progression, promoting an EMT-like phenotype and drug resistance in hormone-independent HER2 + breast cancer [160-162]. Given its importance in the transcription of various target genes supporting cell proliferation and metastasis, the therapeutic inhibition of the Wnt/ $\beta$-catenin signaling cascade has a significant role in the management of breast malignancy.

Some evidence relates to curcumin's potential on the modulation of the Wnt / $\beta$-catenin signaling pathway (Figure 6) in breast cancer. It has been previously reported that the growth suppressive impact induced by curcumin in MDA-MB-231 cells is mediated via its regulatory effect on this pathway. A Western blot analysis of treated cells with $20 \mu \mathrm{M}$ curcumin demonstrated the multiple suppressive effects on its components, including the marked downregulation in the expression levels of $\beta$-catenin, Dvl, cyclin D1, and slug proteins. However, the lack of a significant alteration in the expression of the E-cadherin and GSK3 $\beta$ protein was also reported upon exposure of TNBC cells to curcumin [163]. Besides, an immunofluorescence analysis has also illustrated the modification of the sub-cellular localization of Wnt/ $\beta$-catenin pathway elements. Accordingly, these alterations included a significant decline in the cytoplasmic and nuclear expression level of the Dvl protein, along with a marked reduction in the nuclear level of $\beta$-catenin, cyclin D1, and slug in treated TNBC cells. Additionally, the G2/M cell cycle arrest and the enhanced expression of cytokeratin 18 (CK18), as an early event during apoptosis, showed the anti-proliferative activity and apoptosis occurrence, respectively, following curcumin treatment. These finding suggest that curcumin exert its anticancer effect on TNBC cells through the abrogation of Wnt/ $\beta$ catenin signaling mediated via the modulation of its key elements [163]. Existing evidence strongly implies that stem cell markers have been regulated as the downstream target of $\beta$-catenin [164-166]. Curcumin's vital role in the modulation of metastases and cancer stem cell activity has been shown to be mediated through the Wnt/ $\beta$-catenin pathway inhibition. The study conducted on MDA-MB-231 and its derived breast cancer stem cells (BCSC) revealed that the anti-metastatic effect of curcumin was induced through the regulation of EMT-related markers, including $\beta$-catenin, vimentin, E-cadherin, $\mathrm{N}$-cadherin, and fibronectin. The suppression of stem cell-like characteristics via the downregulation of Sox2, Oct4, and Nanog was also detected in treated TNBC cells [167]. Similar results have also been obtained with curcumin against SUM159 BCSCs. The results showed that curcumin suppressed GSK3 $\beta$ phosphorylation, in its inactive form, leading to the reduced expression of $\beta$-catenin and its downstream target c-myc in treated BCSCs. In line with these results, the downregulation of stem cell markers including CD44, Nanog, ALDH1A1, and Oct4 was also observed. Besides, the suppression of the sonic hedgehog pathway due to the downregulatory effect of curcumin on shh, Smo, Gli1, and Gli2 contributed to BCSC inhibition [168]. Another report also indicated that curcumin exerts its anti-invasive properties on MDA-MB-231 cells through the downregulation of EMT-related genes such as $\beta$-catenin, $\mathrm{N}$-cadherin, vimentin, and $\mathrm{AXL}$, representing its capability to hinder the EMT process [43]. 


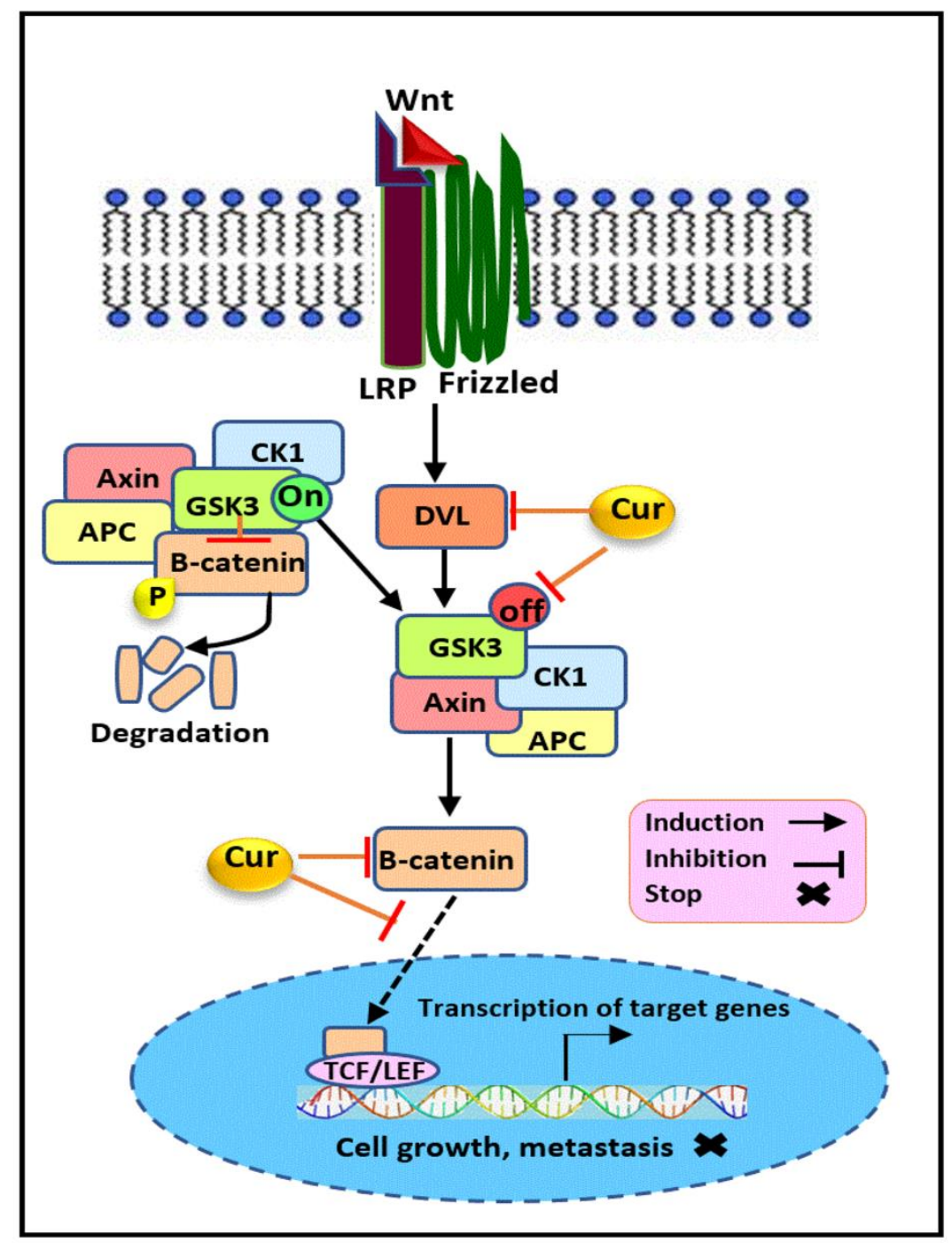

Figure 6. The modulatory effect of curcumin on the Wnt/ $\beta$-catenin pathway. Curcumin inhibits the Wnt/ $\beta$-catenin signaling pathway through the regulation of its key elements. Curcumin downregulates $\beta$-catenin, Dvl, and the inactive form of GSK3 and inhibits $\beta$-catenin translocation into the nucleus, which results in the suppression of cellular proliferation and metastasis in hormone receptor negative breast cancer. Cur: curcumin, Wnt: wingless/integrated, Dvl: disheveled, LRP: lipoprotein receptor-related protein, GSK3: glycogen synthase kinase-3, APC: adenomatous polyposis coli, CK1: Casein kinase 1, TCF/LEF: T cell factor/lymphoid enhancer factor.

\subsection{Apoptosis}

Apoptosis is a highly regulated process of programmed cell death, with a critical role in the normal tissue homeostasis and development. It also occurs as a defense mechanism to eliminate potentially cancerous, damaged, and virus-infected cells $[169,170]$. Apoptosis machinery is conducted through two distinct signaling pathways. A mitochondriamediated (intrinsic) pathway triggered by hypoxia, oxidative stress, and DNA damage involves the release of cytochrome-c from the mitochondrial intermembrane space into cytosol, followed by apoptosome complex formation and caspase- 9 activation. Anti- and pro-apoptotic members of the Bcl-2 family also regulate the permeabilization of the mitochondrial outer membrane $[171,172]$. However, the death receptor-mediated (extrinsic) pathway is stimulated by the interaction of extracellular death ligands such as TNF- $\alpha$, FAS, and TRAIL, with their corresponding death receptors of the TNF receptor superfamily. This receptor-ligand binding triggers DISC complex formation and subsequently caspase$8 / 10$ proteolytic activation. Both pathways eventually activate caspase- 3 and 7 , executing 
cell death $[172,173]$. In addition to these two conventional pathways, the NF-kB, MAPK, PI3k/AKT, STAT3, and $\beta$-Catenin pathways may also induce apoptosis [174-180].

In addition to its physiological significance, the deregulation of apoptosis is critically involved in the pathogenesis of various diseases, ranging from cancer to neurodegenerative disorders. It is well established that the evasion of apoptosis may promote tumor initiation, progression, metastasis, and resistance to therapy in breast cancer $[172,181,182]$. Reduced apoptosis or its resistance in cancer cells can be mediated through numerous mechanisms. For instance, the overexpression of the pro-survival Bcl-2 protein is common in TNBC breast cancer. Besides, Bcl-2 is upregulated in approximately $50 \%$ of hormoneindependent HER2+ breast cancers, which makes it a clinical prognostic marker in breast cancer [183-187]. There is also a close relationship between dysregulated caspase expression and the development of hormone-independent breast cancer which is also involved in its clinicopathological features and poor overall survival $[188,189]$. Altered death receptor signaling also contributes to apoptosis resistance in breast cancer [190-192]. Collectively, given the critical role of apoptosis evasion in promoting the pathogenesis and progression of breast cancer tumors, therapeutic targeting of the apoptotic machinery in cancer cells holds great promise in the anticancer drug discovery and development.

Curcumin has been proven to promote cellular apoptosis by altering the expression of various cellular molecules, as shown in Figure 5. Poly (ADP-ribose) polymerase (PARP) is implicated in DNA repair, cell survival, transcriptional regulation, and apoptosis. The cleavage of PRAP into its fragments causes its enzymatic role deactivation, which eventually leads to cell death $[193,194]$. It was shown that curcumin increased cleaved PARP, cleaved caspase-3, cleaved caspase-7, cleaved caspase-9, caspase-3, caspase-8, cytochrome-c, Bax, and Bid expression and decreased Bcl-2, Mcl-1, and Bcl-xL expression, which resulted in apoptosis induction in MDA-MB-231 cells and tumor growth inhibition in an in vivo xenograft model [142,195-197]. Besides, the downregulation of caspase-3 expression was also observed in curcumin-treated MDA-MB-231 [198]. Moreover, curcumin-induced apoptosis was accompanied by increased caspase- 3 and PARP cleavage, Bax upregulation, and surviving downregulation in SKBR-3, MDA-MB-231/HER2 cells, MDA-MB-468, and HCC1806 [108,199,200].

Another mechanism of curcumin-induced apoptotic cell death is through altering the expression of miRNAs. Curcumin upregulated the expression of miR-15a and miR-16 in SKBR-3 cells, which resulted in decreased Bcl-2 expression and apoptosis occurrence [201]. In another study, curcumin suppressed the proliferation, invasion, and induced apoptosis via the miR181b upregulation and subsequent CXCL-1 and -2 downregulation, as the pro-metastatic and inflammatory cytokines, in MDA-MB-231 cells [128]. A further study also revealed that curcumin-induced miR-34a expression led to the downregulation of Bcl-2 and Bmi-1 proteins in MDA-MB-231 and MDA-MB-435 [202]. In addition, curcumininduced apoptosis is also linked to its ability to trigger ROS generation. It was shown that curcumin upregulated the polyamine catabolic enzyme expressions, PAO and SSAT, which resulted in ROS induction and the subsequent activation of intrinsic and extrinsic apoptotic pathways in wide-type and growth-hormone-expressing MDA-MB-453 and MDA-MB231 cells [81]. Besides, the involvement of ROS induction by curcumin in mitochondrial dysfunction increased cleaved PARP and caspase-3, and the Bax/Bcl-2 expression ratio has been determined in MDA-MB-231 and SKBR-3 cells [56,203].

Furthermore, fatty acid synthase (FAS) is a key metabolic enzyme that is highly expressed in breast cancer and is therefore a putative tumor target. It was shown that curcumin treatment inhibited the cell growth and induced apoptosis dose-dependently, via the inhibition of FAS in MDA-MB-231 cells. This inhibition was associated with the regulation of AKT phosphorylation, Bax, and Bcl-2 protein expressions [204]. FAS inhibition-mediated apoptosis was also reported in curcumin-treated SKBR-3 cells [205]. Moreover, Tafazzin (TAZ) and Yes-associated protein (YAP) are the key effectors of the Hippo signaling pathway. The upregulation of TAZ and YAP is involved in cellular proliferation, EMT, apoptosis suppression, and therapeutic resistance in breast cancer [206,207]. In a recent study, it was 
shown that curcumin downregulated TAZ and YAP expression in MDA-MB-231 cells and tumor xenografts in mice. These alterations inhibit the proliferation, migration, invasion, apoptosis induction, and tumor growth suppression in TNBC models [208]. In addition, ion channels play a significant role in tumorigenesis due to their function in proliferation, apoptosis, and metastasis [209-212]. A recent research has shown that curcumin regulated the expression levels of potassium and non-potassium ion channel genes, which resulted in the upregulation of cleaved caspase-3, cytochrome $c$, and haem oxygenase-1, along with the downregulation of cIAP-1, claspin, and survivin protein in MDA-MB-231 cells [147]. Curcumin-mediated apoptosis could also be linked to its potential to induce DNA damage and increase the expression level of H2AFX, PARP1, BRCA1, and RAD51 in treated MDA-MB-231, HCC1937, MDA-MB-468, and HCC1806 cells [200,213].

Epigenetically mediated apoptosis is another underlying mechanism of curcumin. The expression level of the enhancer of zeste homolog 2 (EZH2), deleted in liver cancer 1 (DLC1), is negatively correlated in breast cancer, where the upregulation of EZH2 and the downregulation of DLC1 have been reported in breast cancer tissue and MDA-MB-231 cells. It was found that curcumin restored DLC1 expression by inhibiting EZH2 expression, which led to growth inhibition and apoptosis induction in MDA-MB-231 cells and in an in vivo xenograft model [214]. Additionally, Ras-association domain family 1 isoform A (RASSF1A) is a potential tumor suppressor correlated with the modulator of apoptosis 1 (MOAP-1), which promotes Bax conformational changes and its activation. It was found that curcumin suppressed cell proliferation and induced apoptosis via the upregulation of the RASSF1A, Bax, and caspase-3 protein expression in MDA-MB-231 and MDA-MB-468 cells [215-217].

\subsection{Cell Cycle}

Cell cycle is a highly regulated process of cell duplication which involves several checkpoints to ensure its proper progression. Multiple cyclins and cyclin-dependent kinases (CDK) form cyclin-CDK complexes which determine a cell progression through the cycle. However, when the cells no longer divide, cyclins are degraded and, subsequently, the deactivation of CDKs and cell cycle arrest occur [218-220]. Besides, CDK inhibitors (CDKIs) comprised of Ink4 (inhibitor of CDK-4) including p15, p16, p18, and p19 and kinase inhibitor protein (Kip) including p21, p27, and p57 as well as retinoblastoma (RB1) protein negatively regulate the cell cycle progression. [219,221,222].

The cell cycle machinery was deregulated at multiple levels in breast cancer cells, promoting cancer development and resistance to therapy $[219,223,224]$. Cyclin D1 is probably the most extensively studied cyclin in breast tumors, and its overexpression has been reported in more than 50\% of breast cancer cases, as detected in TNBC and hormoneindependent HER2+ [224,225]. Cyclin D1 also has CDK independent functions through its binding to histone acetylases, histone deacetylases, and nuclear receptors to regulate cell proliferation, growth, and differentiation. Moreover, it functions in the DNA repair system by binding to RAD51 involved in the homologous recombination of DNA during double strand break repair [225-228]. TNBC also display a frequent alteration of RB1 and the DNA damage response gene, BRCA1. Besides, overexpression of the CDK4 is also a common feature among breast cancer types, with the highest frequency in the hormone-independent HER2+ subtype $[224,229]$. Thereby, due to their vital role in breast cancer cell proliferation, the cell cycle regulatory proteins are the potential targets in cancer therapy.

Curcumin has been shown to inhibit the cell cycle progression in various phases and alter the expression of different cell cycle proteins in TNBC and hormone-independent HER2+ breast cancer (Figure 5). It has been previously reported that curcumin treatment caused an increase in the accumulation of cells in the $S$ and G2/M phases in MDA-MB-468 cells and exerted its dual impact on cancer cell progression [54]. It was also found that a $10 \mu \mathrm{M}$ concentration of curcumin led to $\mathrm{G} 2 / \mathrm{M}$ phase arrest, accompanied by the upregulation of p21 expression and the downregulation of cyclin A, B1, D1, and E expression in SKBR-3 cells [56]. In addition, the induction of G0/G1 cell cycle arrest was associated with 
p21 and p27 upregulation and cyclin D1 downregulation in SKBR-3 cells [108]. Another report revealed that the curcumin-mediated EZH2 downregulation is correlated with the G1 arrest in MDA-MB-435 cells [104]. Furthermore, a recent study has shown that curcumin inhibited the expression of cyclin D and cyclin E in SKBR-3 and MDA-MB-231 cells [230]. Besides, curcumin upregulated p21, p16, and p53 and downregulated cyclin E, cyclin D1, CDK-2, and CDK-4 in MDA-MB-231 cells. These effects were mediated via ROS induction and p38-MAPK activity, which led to G1/S and G2/M arrest and cell death in treated cells $[143,197]$. In addition, the downregulation of STAT3-mediated cyclin D1 and c-Myc following curcumin treatment resulted in G1 arrest in MDA-MB-231 [142]. An increased p21 and p53 expression along with a reduced $\mathrm{Rb}$ protein expression also caused G2/M cell cycle arrest in MDA-MB-231 and MDA-MB-453 cells [81,106]. The reports also revealed the upregulation of p27 and p21 expression and the downregulation of cyclin E, CDK-2, and CDK-4 via curcumin-mediated SKP2 inhibition in MDA-MB-231 and MDA-MB-231/HER2 cells $[57,199]$. Additionally, the downregulation of PCNA, RAD50, RAD51, Nbs1, BRCA1, BRCA2, and Mre11, involved in the DNA damage response and repair, was observed in curcumin-treated MDA-MB-231 cells $[143,198,231]$. Curcumin also regulated the cellular localization of BRCA1 by triggering its cytoplasmic retention in MDA-MB-468 and HCC1806, having functional BRCA1, but not in BRCA1-defective HCC1937 [200].

\section{Clinical Trial}

A large number of reported preclinical studies of in vitro and in vivo models support the promising role of curcumin as a potential chemopreventative and chemotherapeutic agent in breast cancer treatment. Accordingly, the clinical research trial of curcumin and its synergistic effect with other chemotherapeutic drugs in enhancing breast cancer therapy have been evidenced. In a phase I clinical trial conducted in 2010 in 14 patients with advanced and metastatic breast cancer, the feasibility and tolerability of curcumin, docetaxel chemotherapy, as a microtubule inhibitor, and their combination were explored. In this trial, a daily oral dose of $0.5 \mathrm{~g}$ of curcumin was given and further escalated until a dose-limiting toxicity occurred, along with intravenous docetaxel $\left(100 \mathrm{mg} / \mathrm{m}^{2}\right)$ [232]. Based on the obtained findings, no enhanced incidence of hematological toxicity was observed. However, the tested combination significantly decreased the VEGF levels. Although it was found that a daily administration of $8 \mathrm{~g}$ curcumin is the maximum tolerable dose, the phase II dose of $6 \mathrm{~g} /$ day, 7 days, every 3 weeks, in combination with a standard dose of docetaxel, has been reported to be suitable for further evaluation [232]. Moreover, due to the low bioavailability of curcumin through oral administration, a phase II clinical trial of 150 women investigated the effectiveness and safety of treatment with intravenous curcumin, compared to placebo, in combination with paclitaxel chemotherapy among patients with metastatic and advanced breast cancer [233]. In this trial, the patients received intravenously either paclitaxel $\left(80 \mathrm{mg} / \mathrm{m}^{2}\right)$-placebo or paclitaxel-curcumin (300 mg solution) combinations once a week for 12 weeks. The findings demonstrated that, with respect to the objective response rate and physical performance, curcumin in combination with paclitaxel had a superior impact on patients compared to the placebo after 12 weeks of treatment and a shortterm follow-up. Besides, an adverse effect analysis suggested not only the lack of safety concerns of intravenous curcumin but also its clinical efficacy on the reduction of fatigue, an extreme feeling of tiredness, or a lack of energy as the most common side effects of chemotherapy [233].

Besides, in a phase II study, 30 breast cancer patients undergoing radiotherapy following completion of their chemotherapy have been analyzed in order to investigate the curcumin potential versus placebo to reduce the DNA binding of NF- $\mathrm{KB}$ and the activation of its downstream target. In this study, curcumin as Meriva (500 mg BID), which is a curcumin formulation improving its absorption, has been orally given to the respective patients. The researchers propose that, by decreasing the activity of NF- $\mathrm{KB}$ and ultimately plasma IL-6, fatigue may improve in breast cancer patients taking Meriva [230]. Currently, a phase I clinical trial study is recruiting 20 participants in order to assess the effect of 
the oral administration of curcumin on apoptosis- and cell proliferation-related biological changes in primary tumors of invasive breast cancer patients (stages I, II, or III) [234].

\section{Conclusions}

Overall, the molecular basis of hormone-independent breast cancer is correlated with the dysregulation of various key signaling cascades consisting of the PI3K/Akt/mTOR pathway, JAK/STAT pathway, MAPK pathway, NF-kB pathway, p53 pathway, Wnt/ $\beta$ catenin, and apoptosis and cell cycle pathways. The current review deepens and expands our knowledge of anti-breast cancer activity of curcumin by interfering with these oncogenic signaling pathways, which leads to the regulation of cell survival and proliferation, metastasis, angiogenesis, cancer stem cell, and cell death in TNBC and hormoneindependent HER2+ breast cancer. Curcumin has been shown to interact with multiple molecular targets including various kinases, transcription and growth factors, receptors, apoptosis, and cell cycle regulatory molecules, etc., to exert its therapeutic role in hormoneindependent breast cancer, as shown in Figure 7. Therefore, a detailed understanding of its multifunctional anticancer action may provide a framework for future studies and insights to improve its efficiency in clinical practice. Moreover, curcumin has enhanced the effectiveness of the chemotherapeutic drugs paclitaxel, gemcitabine, doxorubicin, 5-fluorouracil, and docetaxel and overcome drug resistance in hormone-independent breast cancer, warranting the further exploration of various curcumin-therapeutic agents' synergism in a larger scale of pre-clinical and clinical studies. In clinical studies, its application either alone or in combination has also revealed its significant role in improving breast cancer therapy and reducing adverse effects such as fatigue and radiation-induced dermatitis in patients. Additionally, the development of a novel curcumin formulation and a more efficient delivery system continues to be a subject of great interest for overcoming its poor bioavailability, which limits its clinical applications.

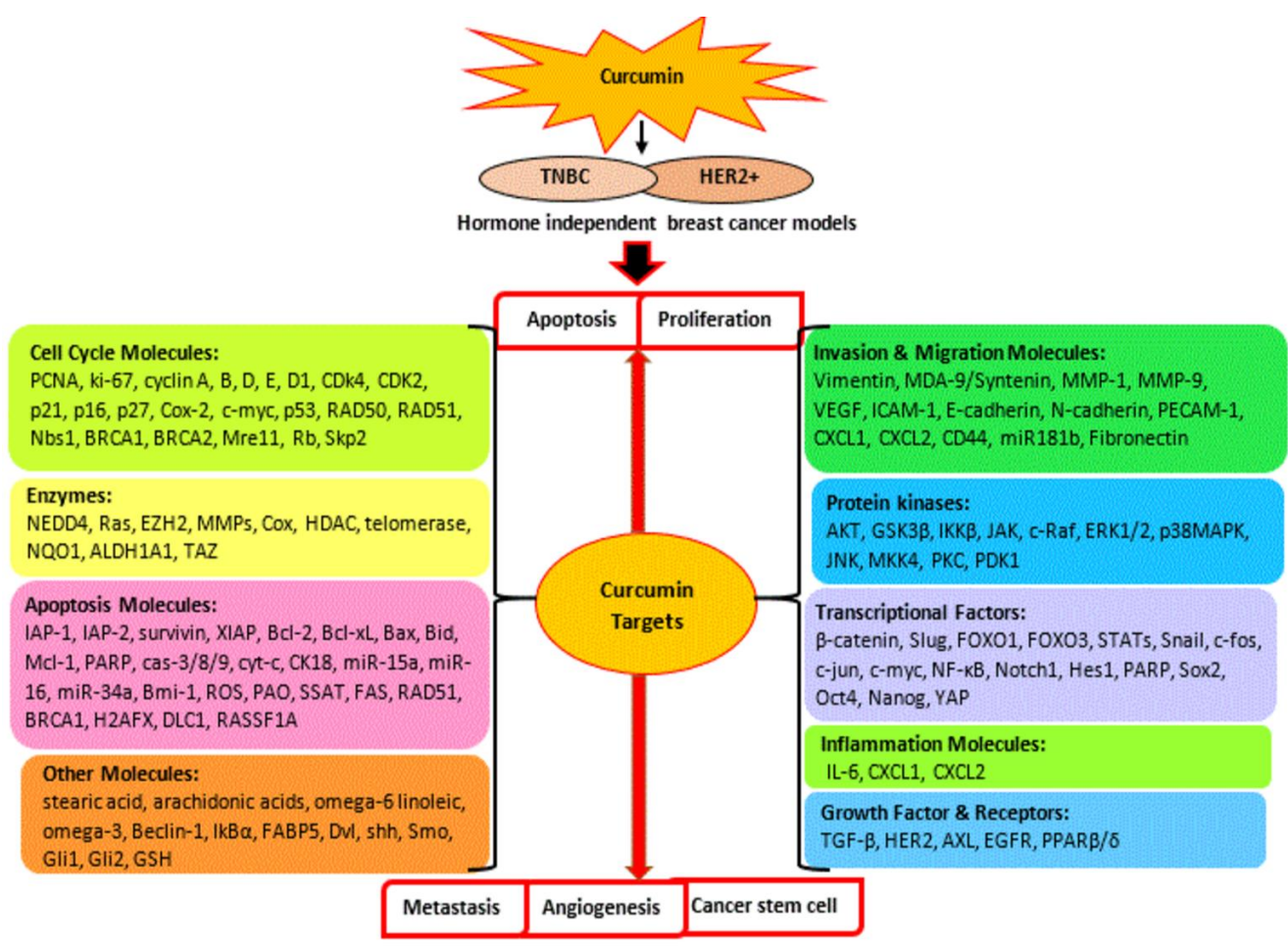

Figure 7. Multi-target action of curcumin against TNBC and hormone-independent HER2 positive breast cancer. Curcumin induces apoptotic cell death and suppresses cellular growth, proliferation, metastasis, angiogenesis, and cancer stem cell through the regulation of multiple molecular targets. 
Author Contributions: Conceptualization, R.F. and R.N.; investigation: R.F. and R.N.; writingoriginal draft preparation, R.F; writing - review and editing, R.F. and R.N. Both authors have read and agreed to the published version of the manuscript.

Funding: This study received no funding.

Institutional Review Board Statement: Not applicable.

Informed Consent Statement: Nor applicable.

Acknowledgments: The authors would like to thank Jeffrey Cheah School of Medicine \& Health Sciences, Monash University, Malaysia, for providing the research facilities and support to conduct this study.

Conflicts of Interest: The authors declare no conflict of interest.

\section{References}

1. World Health Organization (WHO). Global Health Estimates 2020: Deaths by Cause, Age, Sex, by Country and by Region, 20002019. Available online: https://www.who.int/data/gho/data/themes/mortality-and-global-health-estimates/ghe-leadingcauses-of-death (accessed on 25 March 2021).

2. Sung, H.; Ferlay, J.; Siegel, R.L.; Laversanne, M.; Soerjomataram, I.; Jemal, A.; Bray, F. Global cancer statistics 2020: GLOBOCAN estimates of incidence and mortality worldwide for 36 cancers in 185 countries. CA Cancer J. Clin. 2021, 71, 209-249. [CrossRef]

3. Bray, F.; McCarron, P.; Parkin, D.M. The changing global patterns of female breast cancer incidence and mortality. Breast Cancer Res. 2004, 6, 229-239. [CrossRef] [PubMed]

4. Heer, E.; Harper, A.; Escandor, N.; Sung, H.; McCormack, V.; Fidler-Benaoudia, M.M. Global burden and trends in premenopausal and postmenopausal breast cancer: A population-based study. Lancet Glob. Health 2020, 8, e1027-e1037. [CrossRef]

5. Joko-Fru, W.Y.; Jedy-Agba, E.; Korir, A.; Ogunbiyi, O.; Dzamalala, C.P.; Chokunonga, E.; Wabinga, H.; Manraj, S.; Finesse, A.; Somdyala, N. The evolving epidemic of breast cancer in sub-Saharan Africa: Results from the African Cancer Registry Network. Int. J. Cancer 2020, 147, 2131-2141. [CrossRef]

6. Yersal, O.; Barutca, S. Biological subtypes of breast cancer: Prognostic and therapeutic implications. World J. Clin. Oncol. 2014, 5, 412. [CrossRef]

7. Baliu-Piqué, M.; Pandiella, A.; Ocana, A. Breast Cancer Heterogeneity and Response to Novel Therapeutics. Cancers 2020, $12,3271$. [CrossRef]

8. Dai, X.; Xiang, L.; Li, T.; Bai, Z. Cancer hallmarks, biomarkers and breast cancer molecular subtypes. J. Cancer 2016, 7, 1281. [CrossRef]

9. Holliday, D.L.; Speirs, V. Choosing the right cell line for breast cancer research. Breast Cancer Res. 2011, 13, 1-7. [CrossRef] [PubMed]

10. Fan, W.; Chang, J.; Fu, P. Endocrine therapy resistance in breast cancer: Current status, possible mechanisms and overcoming strategies. Future Med. Chem. 2015, 7, 1511-1519. [CrossRef]

11. Lim, E.; Palmieri, C.; Tilley, W.D. Renewed interest in the progesterone receptor in breast cancer. Br. J. Cancer 2016, 115, 909-911. [CrossRef]

12. Iqbal, N.; Iqbal, N. Human epidermal growth factor receptor 2 (HER2) in cancers: Overexpression and therapeutic implications. Mol. Biol. Int. 2014, 2014, 852748. [CrossRef] [PubMed]

13. Schedin, T.B.; Borges, V.F.; Shagisultanova, E. Overcoming therapeutic resistance of triple positive breast cancer with CDK4/6 inhibition. Int. J. Breast Cancer 2018, 2018, 7835095. [CrossRef] [PubMed]

14. Sinha, D.; Biswas, J.; Sung, B.; B Aggarwal, B.; Bishayee, A. Chemopreventive and chemotherapeutic potential of curcumin in breast cancer. Curr. Drug Targets 2012, 13, 1799-1819. [CrossRef]

15. O'Sullivan, C.C.; Smith, K.L. Therapeutic Considerations When Treating HER2-positive Metastatic Breast Cancer. Curr. Breast Cancer Rep. 2014, 6, 169-182. [CrossRef]

16. Sodergren, S.C.; Copson, E.; White, A.; Efficace, F.; Sprangers, M.; Fitzsimmons, D.; Bottomley, A.; Johnson, C.D. Systematic review of the side effects associated with anti-HER2-targeted therapies used in the treatment of breast cancer, on behalf of the EORTC quality of life group. Target. Oncol. 2016, 11, 277-292. [CrossRef]

17. Dent, R.; Trudeau, M.; Pritchard, K.I.; Hanna, W.M.; Kahn, H.K.; Sawka, C.A.; Lickley, L.A.; Rawlinson, E.; Sun, P.; Narod, S.A. Triple-negative breast cancer: Clinical features and patterns of recurrence. Clin. Cancer Res. 2007, 13, 4429-4434. [CrossRef]

18. Bianchini, G.; Balko, J.M.; Mayer, I.A.; Sanders, M.E.; Gianni, L. Triple-negative breast cancer: Challenges and opportunities of a heterogeneous disease. Nat. Rev. Clin. Oncol. 2016, 13, 674. [CrossRef]

19. Bimonte, S.; Cascella, M.; Barbieri, A.; Arra, C.; Cuomo, A. Current shreds of evidence on the anticancer role of EGCG in triple negative breast cancer: An update of the current state of knowledge. Infect. Agents Cancer 2020, 15, 1-6. [CrossRef]

20. Singh, S.; Sharma, B.; Kanwar, S.S.; Kumar, A. Lead phytochemicals for anticancer drug development. Front. Plant Sci. 2016, 7, 1667. [CrossRef] 
21. Luo, H.; Vong, C.T.; Chen, H.; Gao, Y.; Lyu, P.; Qiu, L.; Zhao, M.; Liu, Q.; Cheng, Z.; Zou, J. Naturally occurring anti-cancer compounds: Shining from Chinese herbal medicine. Chin. Med. 2019, 14, 1-58. [CrossRef]

22. Banik, U.; Parasuraman, S.; Adhikary, A.K.; Othman, N.H. Curcumin: The spicy modulator of breast carcinogenesis. J. Exp. Clin. Cancer Res. 2017, 36, 1-16. [CrossRef]

23. Norouzi, S.; Majeed, M.; Pirro, M.; Generali, D.; Sahebkar, A. Curcumin as an adjunct therapy and microRNA modulator in breast cancer. Curr. Pharm. Des. 2018, 24, 171-177. [CrossRef]

24. Agrawal, D.K.; Mishra, P.K. Curcumin and its analogues: Potential anticancer agents. Med. Res. Rev. 2010, 30, 818-860. [CrossRef]

25. Prasad, S.; Aggarwal, B.B. Turmeric, the Golden Spice: From Traditional Medicine to Modern Medicine. In Herbal Medicine: Biomolecular and Clinical Aspects; Benzie, I.F.F., Wachtel-Galor, S., Eds.; CRC Press/Taylor and Francis Group, LLC.: Boca Raton, FL, USA, 2011.

26. Wang, Y.; Yu, J.; Cui, R.; Lin, J.; Ding, X. Curcumin in treating breast cancer: A review. J. Lab. Autom. 2016, 21, 723-731. [CrossRef]

27. Liu, D.; Chen, Z. The effect of curcumin on breast cancer cells. J. Breast Cancer 2013, 16, 133. [CrossRef]

28. Song, X.; Zhang, M.; Dai, E.; Luo, Y. Molecular targets of curcumin in breast cancer. Mol. Med. Rep. 2019, 19, 23-29. [CrossRef]

29. Sun, X.-D.; Liu, X.-E.; Huang, D.-S. Curcumin induces apoptosis of triple-negative breast cancer cells by inhibition of EGFR expression. Mol. Med. Rep. 2012, 6, 1267-1270. [CrossRef]

30. Pugazhenthi, S.; Nesterova, A.; Sable, C.; Heidenreich, K.A.; Boxer, L.M.; Heasley, L.E.; Reusch, J.E.-B. Akt/protein kinase B up-regulates Bcl-2 expression through cAMP-response element-binding protein. J. Biol. Chem. 2000, 275, 10761-10766. [CrossRef]

31. Liu, R.; Chen, Y.; Liu, G.; Li, C.; Song, Y.; Cao, Z.; Li, W.; Hu, J.; Lu, C.; Liu, Y. PI3K/AKT pathway as a key link modulates the multidrug resistance of cancers. Cell Death Dis. 2020, 11, 1-12. [CrossRef]

32. Ortega, M.A.; Fraile-Martínez, O.; Asúnsolo, Á.; Buján, J.; García-Honduvilla, N.; Coca, S. Signal Transduction Pathways in Breast Cancer: The Important Role of PI3K/Akt/mTOR. J. Oncol. 2020, 2020, 1-11. [CrossRef]

33. Chan, J.J.; Tan, T.J.; Dent, R.A. Novel therapeutic avenues in triple-negative breast cancer: PI3K/AKT inhibition, androgen receptor blockade, and beyond. Ther. Adv. Med. Oncol. 2019, 11, 1758835919880429. [CrossRef]

34. Singel, S.M.; Cornelius, C.; Zaganjor, E.; Batten, K.; Sarode, V.R.; Buckley, D.L.; Peng, Y.; John, G.B.; Li, H.C.; Sadeghi, N.; et al. KIF14 promotes AKT phosphorylation and contributes to chemoresistance in triple-negative breast cancer. Neoplasia 2014, 16, 247-256.e242. [CrossRef]

35. Massihnia, D.; Galvano, A.; Fanale, D.; Perez, A.; Castiglia, M.; Incorvaia, L.; Listì, A.; Rizzo, S.; Cicero, G.; Bazan, V. Triple negative breast cancer: Shedding light onto the role of pi3k/akt/mtor pathway. Oncotarget 2016, 7, 60712. [CrossRef]

36. Fujimoto, Y.; Morita, T.Y.; Ohashi, A.; Haeno, H.; Hakozaki, Y.; Fujii, M.; Kashima, Y.; Kobayashi, S.S.; Mukohara, T. Combination treatment with a PI3K/Akt/mTOR pathway inhibitor overcomes resistance to anti-HER2 therapy in PIK3CA-mutant HER2positive breast cancer cells. Sci. Rep. 2020, 10, 1-16. [CrossRef]

37. Cossu-Rocca, P.; Orrù, S.; Muroni, M.R.; Sanges, F.; Sotgiu, G.; Ena, S.; Pira, G.; Murgia, L.; Manca, A.; Uras, M.G. Analysis of PIK3CA mutations and activation pathways in triple negative breast cancer. PLoS ONE 2015, 10, e0141763. [CrossRef]

38. Khan, M.A.; Jain, V.K.; Rizwanullah, M.; Ahmad, J.; Jain, K. PI3K/AKT/mTOR pathway inhibitors in triple-negative breast cancer: A review on drug discovery and future challenges. Drug Discov. Today 2019, 24, 2181-2191. [CrossRef]

39. Castaneda, C.A.; Cortes-Funes, H.; Gomez, H.L.; Ciruelos, E.M. The phosphatidyl inositol 3-kinase/AKT signaling pathway in breast cancer. Cancer Metastasis Rev. 2010, 29, 751-759. [CrossRef]

40. Tewari, D.; Patni, P.; Bishayee, A.; Sah, A.N.; Bishayee, A. Natural products targeting the PI3K-Akt-mTOR signaling pathway in cancer: A novel therapeutic strategy. Semin. Cancer Biol. 2019. [CrossRef]

41. Guan, F.; Ding, Y.; Zhang, Y.; Zhou, Y.; Li, M.; Wang, C. Curcumin suppresses proliferation and migration of MDA-MB-231 breast cancer cells through autophagy-dependent Akt degradation. PLoS ONE 2016, 11, e0146553. [CrossRef]

42. Zhang, G.; Kong, X.; Wang, M.; Zhao, H.; Han, S.; Hu, R.; Huang, J.; Cui, W. AXL is a marker for epithelial-mesenchymal transition in esophageal squamous cell carcinoma. Oncol. Lett. 2018, 15, 1900-1906. [CrossRef]

43. Gallardo, M.; Calaf, G.M. Curcumin inhibits invasive capabilities through epithelial mesenchymal transition in breast cancer cell lines. Int. J. Oncol. 2016, 49, 1019-1027. [CrossRef]

44. Zhu, Q.-S.; Rosenblatt, K.; Huang, K.-L.; Lahat, G.; Brobey, R.; Bolshakov, S.; Nguyen, T.; Ding, Z.; Belousov, R.; Bill, K. Vimentin is a novel AKT1 target mediating motility and invasion. Oncogene 2011, 30, 457-470. [CrossRef]

45. Chen, W.-C.; Lai, Y.-A.; Lin, Y.-C.; Ma, J.-W.; Huang, L.-F.; Yang, N.-S.; Ho, C.-T.; Kuo, S.-C.; Way, T.-D. Curcumin suppresses doxorubicin-induced epithelial-mesenchymal transition via the inhibition of TGF- $\beta$ and PI3K/AKT signaling pathways in triple-negative breast Cancer cells. J. Agric. Food Chem. 2013, 61, 11817-11824. [CrossRef]

46. Lee, D.-F.; Kuo, H.-P.; Chen, C.-T.; Hsu, J.-M.; Chou, C.-K.; Wei, Y.; Sun, H.-L.; Li, L.-Y.; Ping, B.; Huang, W.-C. IKK $\beta$ suppression of TSC1 links inflammation and tumor angiogenesis via the mTOR pathway. Cell 2007, 130, 440-455. [CrossRef]

47. Tamaddoni, A.; Mohammadi, E.; Sedaghat, F.; Qujeq, D.; As'Habi, A. The anticancer effects of curcumin via targeting the mammalian target of rapamycin complex 1 (mTORC1) signaling pathway. Pharmacol. Res. 2020, 156, 104798. [CrossRef]

48. Wan, L.; Liu, T.; Hong, Z.; Pan, Y.; Sizemore, S.T.; Zhang, J.; Ma, Z. NEDD4 expression is associated with breast cancer progression and is predictive of a poor prognosis. Breast Cancer Res. 2019, 21, 1-16. [CrossRef]

49. Jeon, S.; Kim, D.W.; Lee, D.-B.; Cho, J.-Y. NEDD4 Plays Roles in the Maintenance of Breast Cancer Stem Cell Characteristics. Front. Oncol. 2020, 10, 1680. [CrossRef] 
50. Wang, X.; Trotman, L.C.; Koppie, T.; Alimonti, A.; Chen, Z.; Gao, Z.; Wang, J.; Erdjument-Bromage, H.; Tempst, P.; Cordon-Cardo, C. NEDD4-1 is a proto-oncogenic ubiquitin ligase for PTEN. Cell 2007, 128, 129-139. [CrossRef]

51. Amodio, N.; Scrima, M.; Palaia, L.; Salman, A.N.; Quintiero, A.; Franco, R.; Botti, G.; Pirozzi, P.; Rocco, G.; De Rosa, N. Oncogenic role of the E3 ubiquitin ligase NEDD4-1, a PTEN negative regulator, in non-small-cell lung carcinomas. Am. J. Pathol. 2010, 177, 2622-2634. [CrossRef]

52. Hong, S.; Moon, J.; Kim, J.; Shin, J.; Jung, K.; Lee, W.; Jeong, S.; Hwang, J.; Lee, S.; Suh, Y. p34 is a novel regulator of the oncogenic behavior of NEDD4-1 and PTEN. Cell Death Differ. 2014, 21, 146-160. [CrossRef]

53. Chen, Y.; van de Vijver, M.J.; Hibshoosh, H.; Parsons, R.; Saal, L.H. PTEN and NEDD4 in human breast carcinoma. Pathol. Oncol. Res. 2016, 22, 41-47. [CrossRef] [PubMed]

54. Squires, M.S.; Hudson, E.A.; Howells, L.; Sale, S.; Houghton, C.E.; Jones, J.L.; Fox, L.H.; Dickens, M.; Prigent, S.A.; Manson, M.M. Relevance of mitogen activated protein kinase (MAPK) and phosphotidylinositol-3-kinase/protein kinase B (PI3K/PKB) pathways to induction of apoptosis by curcumin in breast cells. Biochem. Pharmacol. 2003, 65, 361-376. [CrossRef]

55. Lai, H.-W.; Chien, S.-Y.; Kuo, S.-J.; Tseng, L.-M.; Lin, H.-Y.; Chi, C.-W.; Chen, D.-R. The potential utility of curcumin in the treatment of HER-2-overexpressed breast cancer: An in vitro and in vivo comparison study with herceptin. Evid.-Based Complement. Alternat. Med. 2012, 2012, 486568. [CrossRef] [PubMed]

56. Venkiteswaran, S.; Hsu, H.; Yang, P.; Thomas, T.; TJ, T. Curcumin interferes with HER-2 signaling in a redox-dependent manner in SK-BR-3 human breast cancer cells. J. Hum. Nutr. Food Sci. 2014, 2, 1-8.

57. Jia, T.; Zhang, L.; Duan, Y.; Zhang, M.; Wang, G.; Zhang, J.; Zhao, Z. The differential susceptibilities of MCF-7 and MDA-MB-231 cells to the cytotoxic effects of curcumin are associated with the PI3K/Akt-SKP2-Cip/Kips pathway. Cancer Cell Int. 2014, 14, 1-14. [CrossRef] [PubMed]

58. Wang, S.-W.; Sun, Y.-M. The IL-6/JAK/STAT3 pathway: Potential therapeutic strategies in treating colorectal cancer. Int. J. Oncol. 2014, 44, 1032-1040. [CrossRef] [PubMed]

59. Ma, J.-h.; Qin, L.; Li, X. Role of STAT3 signaling pathway in breast cancer. Cell Commun. Signal. 2020, 18, 1-13. [CrossRef] [PubMed]

60. Bharadwaj, U.; Kasembeli, M.M.; Robinson, P.; Tweardy, D.J. Targeting Janus kinases and signal transducer and activator of transcription 3 to treat inflammation, fibrosis, and cancer: Rationale, progress, and caution. Pharmacol. Rev. 2020, 72, 486-526. [CrossRef]

61. Chun, J.; Song, K.; Kim, Y.S. Sesquiterpene lactones-enriched fraction of Inula helenium L. induces apoptosis through inhibition of signal transducers and activators of transcription 3 signaling pathway in MDA-MB-231 breast cancer cells. Phytother. Res. 2018, 32, 2501-2509. [CrossRef]

62. Tzeng, Y.T.; Liu, P.F.; Li, J.Y.; Liu, L.F.; Kuo, S.Y.; Hsieh, C.W.; Lee, C.H.; Wu, C.H.; Hsiao, M.; Chang, H.T.; et al. Kinome-Wide siRNA Screening Identifies Src-Enhanced Resistance of Chemotherapeutic Drugs in Triple-Negative Breast Cancer Cells. Front Pharm. 2018, 9, 1285. [CrossRef]

63. Wang, T.; Fahrmann, J.F.; Lee, H.; Li, Y.J.; Tripathi, S.C.; Yue, C.; Zhang, C.; Lifshitz, V.; Song, J.; Yuan, Y.; et al. JAK/STAT3Regulated Fatty Acid $\beta$-Oxidation Is Critical for Breast Cancer Stem Cell Self-Renewal and Chemoresistance. Cell Metab. 2018, 27, 136-150.e135. [CrossRef]

64. Kamran, M.Z.; Patil, P.; Gude, R.P. Role of STAT3 in Cancer Metastasis and Translational Advances. BioMed Res. Int. 2013, 2013, 1-15. [CrossRef]

65. Ma, Q.; Gao, F.F.; He, X.; Li, K.; Gao, Y.; Xu, X.L.; Jiang, N.H.; Ding, L.; Song, W.J.; He, Y.Q. Antitumor effects of saikosaponin b2 on breast cancer cell proliferation and migration. Mol. Med. Rep. 2019, 20, 1943-1951. [CrossRef] [PubMed]

66. Xie, Q.; Yang, Z.; Huang, X.; Zhang, Z.; Li, J.; Ju, J.; Zhang, H.; Ma, J. Ilamycin C induces apoptosis and inhibits migration and invasion in triple-negative breast cancer by suppressing IL-6/STAT3 pathway. J. Hematol. Oncol. 2019, 12, 1-14. [CrossRef] [PubMed]

67. Lin, L.; Hutzen, B.; Zuo, M.; Ball, S.; Deangelis, S.; Foust, E.; Pandit, B.; Ihnat, M.A.; Shenoy, S.S.; Kulp, S. Novel STAT3 phosphorylation inhibitors exhibit potent growth-suppressive activity in pancreatic and breast cancer cells. Cancer Res. 2010, 70, 2445-2454. [CrossRef] [PubMed]

68. Walker, S.R.; Xiang, M.; Frank, D.A. Distinct roles of STAT3 and STAT5 in the pathogenesis and targeted therapy of breast cancer. Mol. Cell. Endocrinol. 2014, 382, 616-621. [CrossRef]

69. Qin, J.-J.; Yan, L.; Zhang, J.; Zhang, W.-D. STAT3 as a potential therapeutic target in triple negative breast cancer: A systematic review. J. Exp. Clin. Cancer Res. 2019, 38, 1-16. [CrossRef] [PubMed]

70. Zhang, Q.; Raje, V.; Yakovlev, V.A.; Yacoub, A.; Szczepanek, K.; Meier, J.; Derecka, M.; Chen, Q.; Hu, Y.; Sisler, J. Mitochondrial localized Stat3 promotes breast cancer growth via phosphorylation of serine 727. J. Biol. Chem. 2013, 288, 31280-31288. [CrossRef]

71. Yang, R.; Rincon, M. Mitochondrial Stat3, the need for design thinking. Int. J. Biol. Sci. 2016, 12, 532. [CrossRef] [PubMed]

72. Yao, A.; Xiang, Y.; Si, Y.R.; Fan, L.J.; Li, J.P.; Li, H.; Guo, W.; He, H.X.; Liang, X.J.; Tan, Y. PKM2 promotes glucose metabolism through a let-7a-5p/Stat3/hnRNP-A1 regulatory feedback loop in breast cancer cells. J. Cell. Biochem. 2019, 120, 6542-6554. [CrossRef]

73. Diaz, N.; Minton, S.; Cox, C.; Bowman, T.; Gritsko, T.; Garcia, R.; Eweis, I.; Wloch, M.; Livingston, S.; Seijo, E. Activation of stat3 in primary tumors from high-risk breast cancer patients is associated with elevated levels of activated SRC and survivin expression. Clin. Cancer Res. 2006, 12, 20-28. [CrossRef] 
74. Duru, N.; Fan, M.; Candas, D.; Menaa, C.; Liu, H.-C.; Nantajit, D.; Wen, Y.; Xiao, K.; Eldridge, A.; Chromy, B.A. HER2-associated radioresistance of breast cancer stem cells isolated from HER2-negative breast cancer cells. Clin. Cancer Res. 2012, 18, 6634-6647. [CrossRef]

75. Furth, P.A. STAT signaling in different breast cancer sub-types. Mol. Cell. Endocrinol. 2014, 382, 612-615. [CrossRef] [PubMed]

76. Lin, L.; Hutzen, B.; Ball, S.; Foust, E.; Sobo, M.; Deangelis, S.; Pandit, B.; Friedman, L.; Li, C.; Li, P.K. New curcumin analogues exhibit enhanced growth-suppressive activity and inhibit AKT and signal transducer and activator of transcription 3 phosphorylation in breast and prostate cancer cells. Cancer Sci. 2009, 100, 1719-1727. [CrossRef] [PubMed]

77. Hutzen, B.; Friedman, L.; Sobo, M.; Lin, L.; Cen, L.; De Angelis, S.; Yamakoshi, H.; Shibata, H.; Iwabuchi, Y.; Lin, J. Curcumin analogue GO-Y030 inhibits STAT3 activity and cell growth in breast and pancreatic carcinomas. Int. J. Oncol. $2009,35,867-872$.

78. Chung, S.S.; Vadgama, J.V. Curcumin and epigallocatechin gallate inhibit the cancer stem cell phenotype via down-regulation of STAT3-NFkB signaling. Anticancer Res. 2015, 35, 39-46. [PubMed]

79. Zhang, W.; Guo, J.; Li, S.; Ma, T.; Xu, D.; Han, C.; Liu, F.; Yu, W.; Kong, L. Discovery of monocarbonyl curcumin-BTP hybrids as STAT3 inhibitors for drug-sensitive and drug-resistant breast cancer therapy. Sci. Rep. 2017, 7, 1-17. [CrossRef]

80. Lieblein, J.; Ball, S.; Hutzen, B.; Liu, Z.; Lin, J. Paracrine signaling from the breast cancer cells stimulates the cell proliferation and Stat3 phosphorylation in non-cancerous mammary epithelial cells and is blocked by dietary agent, curcumin. Cancer Epidemiol. Biomark. Prev. 2007, 16, A126.

81. Coker-Gurkan, A.; Celik, M.; Ugur, M.; Arisan, E.-D.; Obakan-Yerlikaya, P.; Durdu, Z.B.; Palavan-Unsal, N. Curcumin inhibits autocrine growth hormone-mediated invasion and metastasis by targeting NF- $\kappa B$ signaling and polyamine metabolism in breast cancer cells. Amino Acids 2018, 50, 1045-1069. [CrossRef]

82. Fu, S.; Lin, J. Blocking interleukin-6 and interleukin-8 signaling inhibits cell viability, colony-forming activity, and cell migration in human triple-negative breast cancer and pancreatic cancer cells. Anticancer Res. 2018, 38, 6271-6279. [CrossRef]

83. Singh, M.; Ramos, I.; Asafu-Adjei, D.; Quispe-Tintaya, W.; Chandra, D.; Jahangir, A.; Zang, X.; Aggarwal, B.B.; Gravekamp, C. Curcumin improves the therapeutic efficacy of $\mathrm{L}$ isteriaat- $\mathrm{M}$ age-b vaccine in correlation with improved T-cell responses in blood of a triple-negative breast cancer model 4T1. Cancer Med. 2013, 2, 571-582. [CrossRef]

84. Marotta, L.L.; Almendro, V.; Marusyk, A.; Shipitsin, M.; Schemme, J.; Walker, S.R.; Bloushtain-Qimron, N.; Kim, J.J.; Choudhury, S.A.; Maruyama, R.; et al. The JAK2/STAT3 signaling pathway is required for growth of CD44 ${ }^{+} \mathrm{CD} 24^{-}$stem cell-like breast cancer cells in human tumors. J. Clin. Investig. 2011, 121, 2723-2735. [CrossRef] [PubMed]

85. Masjedi, A.; Hashemi, V.; Hojjat-Farsangi, M.; Ghalamfarsa, G.; Azizi, G.; Yousefi, M.; Jadidi-Niaragh, F. The significant role of interleukin-6 and its signaling pathway in the immunopathogenesis and treatment of breast cancer. Biomed. Pharmacother. 2018, 108, 1415-1424. [CrossRef] [PubMed]

86. Chang, Q.; Bournazou, E.; Sansone, P.; Berishaj, M.; Gao, S.P.; Daly, L.; Wels, J.; Theilen, T.; Granitto, S.; Zhang, X. The IL-6/JAK/Stat3 feed-forward loop drives tumorigenesis and metastasis. Neoplasia 2013, 15, 848-IN45. [CrossRef] [PubMed]

87. Morrison, D.K. MAP kinase pathways. Cold Spring Harb. Perspect. Biol. 2012, 4, a011254. [CrossRef] [PubMed]

88. Santarpia, L.; Lippman, S.M.; El-Naggar, A.K. Targeting the MAPK-RAS-RAF signaling pathway in cancer therapy. Expert Opin. Ther. Targets 2012, 16, 103-119. [CrossRef]

89. Burotto, M.; Chiou, V.L.; Lee, J.M.; Kohn, E.C. The MAPK pathway across different malignancies: A new perspective. Cancer 2014, 120, 3446-3456. [CrossRef]

90. Lee, S.; Rauch, J.; Kolch, W. Targeting MAPK signaling in cancer: Mechanisms of drug resistance and sensitivity. Int. J. Mol. Sci. 2020, 21, 1102. [CrossRef]

91. Gholami, S.; Chen, C.; Gao, S.; Lou, E.; Fujisawa, S.; Carson, J.; Nnoli, J.; Chou, T.; Bromberg, J.; Fong, Y. Role of MAPK in oncolytic herpes viral therapy in triple-negative breast cancer. Cancer Gene Ther. 2014, 21, 283-289. [CrossRef] [PubMed]

92. Collignon, J.; Lousberg, L.; Schroeder, H.; Jerusalem, G. Triple-negative breast cancer: Treatment challenges and solutions. Breast Cancer: Targets Ther. 2016, 8, 93.

93. Jiang, W.; Wang, X.; Zhang, C.; Xue, L.; Yang, L. Expression and clinical significance of MAPK and EGFR in triple-negative breast cancer. Oncol. Lett. 2020, 19, 1842-1848. [CrossRef]

94. Merlin, J.-L.; Harlé, A.; Lion, M.; Ramacci, C.; Leroux, A. Expression and activation of P38 MAP kinase in invasive ductal breast cancers: Correlation with expression of the estrogen receptor, HER2 and downstream signaling phosphorylated proteins. Oncol. Rep. 2013, 30, 1943-1948. [CrossRef] [PubMed]

95. Liu, S.; Chen, S.; Zeng, J. TGF- $\beta$ signaling: A complex role in tumorigenesis. Mol. Med. Rep. 2018, 17, 699-704. [CrossRef] [PubMed]

96. Daroqui, M.C.; Vazquez, P.; Bal de Kier Joffé, E.; Bakin, A.V.; Puricelli, L.I. TGF- $\beta$ autocrine pathway and MAPK signaling promote cell invasiveness and in vivo mammary adenocarcinoma tumor progression. Oncol. Rep. 2012, 28, 567-575. [CrossRef]

97. Araki, S.; Eitel, J.A.; Batuello, C.N.; Bijangi-Vishehsaraei, K.; Xie, X.-J.; Danielpour, D.; Pollok, K.E.; Boothman, D.A.; Mayo, L.D. TGF- $\beta 1$-induced expression of human Mdm2 correlates with late-stage metastatic breast cancer. J. Clin. Investig. 2010, 120, 290-302. [CrossRef] [PubMed]

98. Mo, N.; Li, Z.-Q.; Li, J.; Cao, Y.-D. Curcumin inhibits TGF- $\beta 1$-induced MMP-9 and invasion through ERK and Smad signaling in breast cancer MDA-MB-231 cells. Asian Pac. J. Cancer Prev. 2012, 13, 5709-5714. [CrossRef] 
99. Kienhuis, C.B.; Sluyser, M.; de Goeij, C.C.; Koenders, P.G.; Benraad, T.J. Epidermal growth factor receptor levels increase but epidermal growth factor receptor ligand levels decrease in mouse mammary tumors during progression from hormone dependence to hormone independence. Breast Cancer Res. Treat. 1993, 26, 289-295. [CrossRef]

100. Hanikoglu, A.; Kucuksayan, E.; Hanikoglu, F.; Ozben, T.; Menounou, G.; Sansone, A.; Chatgilialoglu, C.; Di Bella, G.; Ferreri, C. Effects of somatostatin, curcumin, and quercetin on the fatty acid profile of breast cancer cell membranes. Can. J. Physiol. Pharmacol. 2020, 98, 131-138. [CrossRef]

101. Cagnol, S.; Chambard, J.C. ERK and cell death: Mechanisms of ERK-induced cell death-apoptosis, autophagy and senescence. FEBS J. 2010, 277, 2-21. [CrossRef]

102. Sui, X.; Kong, N.; Ye, L.; Han, W.; Zhou, J.; Zhang, Q.; He, C.; Pan, H. p38 and JNK MAPK pathways control the balance of apoptosis and autophagy in response to chemotherapeutic agents. Cancer Lett. 2014, 344, 174-179. [CrossRef]

103. Hussein, Y.R.; Sood, A.K.; Bandyopadhyay, S.; Albashiti, B.; Semaan, A.; Nahleh, Z.; Roh, J.; Han, H.D.; Lopez-Berestein, G.; Ali-Fehmi, R. Clinical and biological relevance of enhancer of zeste homolog 2 in triple-negative breast cancer. Hum. Pathol. 2012, 43, 1638-1644. [CrossRef]

104. Hua, W.-F.; Fu, Y.-S.; Liao, Y.-J.; Xia, W.-J.; Chen, Y.-C.; Zeng, Y.-X.; Kung, H.-F.; Xie, D. Curcumin induces down-regulation of EZH2 expression through the MAPK pathway in MDA-MB-435 human breast cancer cells. Eur. J. Pharmacol. 2010, 637, 16-21. [CrossRef]

105. Wang, K.; Zhang, C.; Bao, J.; Jia, X.; Liang, Y.; Wang, X.; Chen, M.; Su, H.; Li, P.; Wan, J.-B. Synergistic chemopreventive effects of curcumin and berberine on human breast cancer cells through induction of apoptosis and autophagic cell death. Sci. Rep. 2016, 6, 1-14. [CrossRef] [PubMed]

106. Wang, L.; Wang, C.; Tao, Z.; Zhao, L.; Zhu, Z.; Wu, W.; He, Y.; Chen, H.; Zheng, B.; Huang, X. Curcumin derivative WZ35 inhibits tumor cell growth via ROS-YAP-JNK signaling pathway in breast cancer. J. Exp. Clin. Cancer Res. 2019, 38, 460. [CrossRef] [PubMed]

107. Filippi, A.; Măru, N.; Carmen, M.; Mocanu, M. Anticancer effects of curcumin in luminal B and HER2 breast cancer cell line models. Rom. Biotechnol. Lett. 2017, 24, 168-175. [CrossRef]

108. Yan, G.; Graham, K.; Lanza-Jacoby, S. Curcumin enhances the anticancer effects of trichostatin a in breast cancer cells. Mol. Carcinog. 2013, 52, 404-411. [CrossRef] [PubMed]

109. Park, S.; Cho, D.H.; Andera, L.; Suh, N.; Kim, I. Curcumin enhances TRAIL-induced apoptosis of breast cancer cells by regulating apoptosis-related proteins. Mol. Cell. Biochem. 2013, 383, 39-48. [CrossRef] [PubMed]

110. Park, M.H.; Hong, J.T. Roles of NF-кB in Cancer and Inflammatory Diseases and Their Therapeutic Approaches. Cells 2016, 5, 15. [CrossRef]

111. Yu, Y.; Wan, Y.; Huang, C. The biological functions of NF-kappaB1 (p50) and its potential as an anti-cancer target. Curr. Cancer Drug Targets 2009, 9, 566-571. [CrossRef]

112. Poma, P.; Labbozzetta, M.; D’Alessandro, N.; Notarbartolo, M. NF- $\kappa$ B is a potential molecular drug target in triple-negative breast cancers. Omics 2017, 21, 225-231. [CrossRef]

113. Wang, W.; Nag, S.A.; Zhang, R. Targeting the NFkB signaling pathways for breast cancer prevention and therapy. Curr. Med. Chem. 2015, 22, 264-289. [CrossRef] [PubMed]

114. Kim, J.-Y.; Jung, H.H.; Ahn, S.; Bae, S.; Lee, S.K.; Kim, S.W.; Lee, J.E.; Nam, S.J.; Ahn, J.S.; Im, Y.-H. The relationship between nuclear factor (NF)- $\mathrm{kB}$ family gene expression and prognosis in triple-negative breast cancer (TNBC) patients receiving adjuvant doxorubicin treatment. Sci. Rep. 2016, 6, 1-11. [CrossRef]

115. Chen, Y.-J.; Yeh, M.-H.; Yu, M.-C.; Wei, Y.-L.; Chen, W.-S.; Chen, J.-Y.; Shih, C.-Y.; Tu, C.-Y.; Chen, C.-H.; Hsia, T.-C. Lapatinibinduced NF-kappaB activation sensitizes triple-negative breast cancer cells to proteasome inhibitors. Breast Cancer Res. 2013, 15, 1-14. [CrossRef]

116. Kendellen, M.F.; Bradford, J.W.; Lawrence, C.L.; Clark, K.S.; Baldwin, A.S. Canonical and non-canonical NF- $\kappa B$ signaling promotes breast cancer tumor-initiating cells. Oncogene 2014, 33, 1297-1305. [CrossRef] [PubMed]

117. Murwanti, R.; Kholifah, E.; Sudarmanto, B.A.; Hermawan, A. Effect of curcumin on NF-кB P105/50 expression on triple-negative breast cancer (TNBC) and its possible mechanism of action. AIP Conf. Proc. 2020, 2260, 040024.

118. Liu, Q.; Loo, W.T.; Sze, S.; Tong, Y. Curcumin inhibits cell proliferation of MDA-MB-231 and BT-483 breast cancer cells mediated by down-regulation of NFKB, cyclinD and MMP-1 transcription. Phytomedicine 2009, 16, 916-922. [CrossRef] [PubMed]

119. Aggarwal, B.B.; Shishodia, S.; Takada, Y.; Banerjee, S.; Newman, R.A.; Bueso-Ramos, C.E.; Price, J.E. Curcumin suppresses the paclitaxel-induced nuclear factor-kappaB pathway in breast cancer cells and inhibits lung metastasis of human breast cancer in nude mice. Clin. Cancer Res. 2005, 11, 7490-7498. [CrossRef] [PubMed]

120. Serasanambati, M.; Chilakapati, S.R.; Manikonda, P.K.; Kanala, J.R. Curcumin potentiates antitumor effect of gemcitabine in human breast cancer in vitro. Invasion Metastasis 2013, 13, 15.

121. Roy, M.; Mukherjee, S.; Sarkar, R.; Biswas, J. Curcumin sensitizes chemotherapeutic drugs via modulation of PKC, telomerase, NF- $\mathrm{kB}$ and HDAC in breast cancer. Ther. Deliv. 2011, 2, 1275-1293. [CrossRef] [PubMed]

122. Vinod, B.; Antony, J.; Nair, H.; Puliyappadamba, V.; Saikia, M.; Narayanan, S.S.; Bevin, A.; Anto, R.J. Mechanistic evaluation of the signaling events regulating curcumin-mediated chemosensitization of breast cancer cells to 5-fluorouracil. Cell Death Dis. 2013, 4, e505. [CrossRef] 
123. Thulasiraman, P.; McAndrews, D.J.; Mohiudddin, I.Q. Curcumin restores sensitivity to retinoic acid in triple negative breast cancer cells. BMC Cancer 2014, 14, 724. [CrossRef] [PubMed]

124. Huang, T.; Chen, Z.; Fang, L. Curcumin inhibits LPS-induced EMT through downregulation of NF- $\mathrm{kB}-$ Snail signaling in breast cancer cells. Oncol. Rep. 2013, 29, 117-124. [CrossRef] [PubMed]

125. Palange, A.L.; Di Mascolo, D.; Singh, J.; De Franceschi, M.S.; Carallo, C.; Gnasso, A.; Decuzzi, P. Modulating the vascular behavior of metastatic breast cancer cells by curcumin treatment. Front. Oncol. 2012, 2, 161. [CrossRef] [PubMed]

126. Bimonte, S.; Barbieri, A.; Palma, G.; Rea, D.; Luciano, A.; D'Aiuto, M.; Arra, C.; Izzo, F. Dissecting the Role of Curcumin in Tumour Growth and Angiogenesis in Mouse Model of Human Breast Cancer. Biomed. Res. Int. 2015, 2015, 1-7. [CrossRef]

127. Bachmeier, B.E.; Mohrenz, I.V.; Mirisola, V.; Schleicher, E.; Romeo, F.; Höhneke, C.; Jochum, M.; Nerlich, A.G.; Pfeffer, U. Curcumin downregulates the inflammatory cytokines CXCL1 and-2 in breast cancer cells via NFkB. Carcinogenesis 2008, 29, 779-789. [CrossRef]

128. Kronski, E.; Fiori, M.E.; Barbieri, O.; Astigiano, S.; Mirisola, V.; Killian, P.H.; Bruno, A.; Pagani, A.; Rovera, F.; Pfeffer, U. miR181b is induced by the chemopreventive polyphenol curcumin and inhibits breast cancer metastasis via down-regulation of the inflammatory cytokines CXCL1 and-2. Mol. Oncol. 2014, 8, 581-595. [CrossRef]

129. Sun, X.; Icli, B.; Wara, A.K.; Belkin, N.; He, S.; Kobzik, L.; Hunninghake, G.M.; Vera, M.P.; Registry, M.; Blackwell, T.S.; et al. MicroRNA-181b regulates NF-kB-mediated vascular inflammation. J. Clin. Investig. 2012, 122, 1973-1990. [CrossRef]

130. Budina-Kolomets, A.; Barnoud, T.; Murphy, M.E. The transcription-independent mitochondrial cell death pathway is defective in non-transformed cells containing the Pro47Ser variant of p53. Cancer Biol. Ther. 2018, 19, 1033-1038. [CrossRef]

131. Reisman, D.; Takahashi, P.; Polson, A.; Boggs, K. Transcriptional Regulation of the p53 Tumor Suppressor Gene in S-Phase of the Cell-Cycle and the Cellular Response to DNA Damage. Biochem. Res. Int. 2012, 2012, 808934. [CrossRef]

132. Fridman, J.S.; Lowe, S.W. Control of apoptosis by p53. Oncogene 2003, 22, 9030-9040. [CrossRef]

133. Chi, S.-W. Structural insights into the transcription-independent apoptotic pathway of p53. BMB Rep. 2014, 47, 167-172. [CrossRef]

134. Kim, J.-Y.; Park, K.; Jung, H.H.; Lee, E.; Cho, E.Y.; Lee, K.H.; Bae, S.Y.; Lee, S.K.; Kim, S.W.; Lee, J.E. Association between mutation and expression of TP53 as a potential prognostic marker of triple-negative breast cancer. Cancer Res. Treat. 2016, $48,1338$. [CrossRef]

135. Li, J.P.; Zhang, X.M.; Zhang, Z.; Zheng, L.H.; Jindal, S.; Liu, Y.J. Association of p53 expression with poor prognosis in patients with triple-negative breast invasive ductal carcinoma. Medicine 2019, 98, e15449. [CrossRef] [PubMed]

136. Dang, D.; Peng, Y. Roles of p53 and p16 in triple-negative breast cancer. Breast Cancer Manag. 2013, 2, 537-544. [CrossRef]

137. Liu, Z.; Jiang, Z.; Gao, Y.; Wang, L.; Chen, C.; Wang, X. TP53 Mutations Promote Immunogenic Activity in Breast Cancer. J. Oncol. 2019, 2019, 5952836. [CrossRef] [PubMed]

138. Choudhuri, T.; Pal, S.; Das, T.; Sa, G. Curcumin selectively induces apoptosis in deregulated cyclin D1-expressed cells at G2 phase of cell cycle in a p53-dependent manner. J. Biol. Chem. 2005, 280, 20059-20068. [CrossRef]

139. Moghtaderi, H.; Sepehri, H.; Attari, F. Combination of arabinogalactan and curcumin induces apoptosis in breast cancer cells in vitro and inhibits tumor growth via overexpression of p53 level in vivo. Biomed. Pharmacother. 2017, 88, 582-594. [CrossRef]

140. Akbarzadeh, I.; Shayan, M.; Bourbour, M.; Moghtaderi, M.; Noorbazargan, H.; Eshrati Yeganeh, F.; Saffar, S.; Tahriri, M. Preparation, Optimization and In-Vitro Evaluation of Curcumin-Loaded Niosome@calcium Alginate Nanocarrier as a New Approach for Breast Cancer Treatment. Biology 2021, 10, 173. [CrossRef] [PubMed]

141. Angelopoulou, A.; Kolokithas-Ntoukas, A.; Fytas, C.; Avgoustakis, K. Folic Acid-Functionalized, Condensed Magnetic Nanoparticles for Targeted Delivery of Doxorubicin to Tumor Cancer Cells Overexpressing the Folate Receptor. ACS Omega 2019, 4, 22214-22227. [CrossRef]

142. Quispe-Soto, E.T.; Calaf, G.M. Effect of curcumin and paclitaxel on breast carcinogenesis. Int. J. Oncol. 2016, 49, 2569-2577. [CrossRef]

143. Meena, R.; Kumar, S.; Kumar, R.; Gaharwar, U.S.; Rajamani, P. PLGA-CTAB curcumin nanoparticles: Fabrication, characterization and molecular basis of anticancer activity in triple negative breast cancer cell lines (MDA-MB-231 cells). Biomed. Pharmacother. 2017, 94, 944-954. [CrossRef]

144. Chiu, T.L.; Su, C.C. Curcumin inhibits proliferation and migration by increasing the Bax to Bcl-2 ratio and decreasing NFkappaBp65 expression in breast cancer MDA-MB-231 cells. Int. J. Mol. Med. 2009, 23, 469-475. [CrossRef] [PubMed]

145. Falah, R.R.; Talib, W.H.; Shbailat, S.J. Combination of metformin and curcumin targets breast cancer in mice by angiogenesis inhibition, immune system modulation and induction of p53 independent apoptosis. Adv. Med. Oncol. 2017, 9, 235-252. [CrossRef]

146. Mittal, L.; Raman, V.; Camarillo, I.G.; Garner, A.L.; Sundararajan, R. Viability and cell cycle studies of metastatic triple negative breast cancer cells using low voltage electrical pulses and herbal curcumin. Biomed. Phys. Eng. Express 2019, 5, 025040. [CrossRef]

147. Mohammed, F.; Rashid-Doubell, F.; Taha, S.; Cassidy, S.; Fredericks, S. Effects of curcumin complexes on MDA-MB-231 breast cancer cell proliferation. Int. J. Oncol. 2020, 57, 445-455. [CrossRef] [PubMed]

148. Bae, Y.-H.; Ryu, J.H.; Park, H.-J.; Kim, K.R.; Wee, H.-J.; Lee, O.-H.; Jang, H.-O.; Bae, M.-K.; Kim, K.-W.; Bae, S.-K. Mutant p53-Notch1 Signaling Axis Is Involved in Curcumin-Induced Apoptosis of Breast Cancer Cells. Korean J. Physiol. Pharm. 2013, 17, 291-297. [CrossRef] [PubMed]

149. Bae, Y.-H.; Shin, J.-M.; Park, H.-J.; Jang, H.-O.; Bae, M.-K.; Bae, S.-K. Gain-of-function mutant p53-R280K mediates survival of breast cancer cells. Genes Genom. 2014, 36, 171-178. [CrossRef] 
150. Patiño-Morales, C.C.; Soto-Reyes, E.; Arechaga-Ocampo, E.; Ortiz-Sánchez, E.; Antonio-Véjar, V.; Pedraza-Chaverri, J.; GarcíaCarrancá, A. Curcumin stabilizes p53 by interaction with NAD (P) H: Quinone oxidoreductase 1 in tumor-derived cell lines. Redox Biol. 2020, 28, 101320. [CrossRef]

151. Wild, S.L.; Elghajiji, A.; Grimaldos Rodriguez, C.; Weston, S.D.; Burke, Z.D.; Tosh, D. The Canonical Wnt Pathway as a Key Regulator in Liver Development, Differentiation and Homeostatic Renewal. Genes 2020, 11, 1163. [CrossRef]

152. Sethi, J.K.; Vidal-Puig, A. Wnt signalling and the control of cellular metabolism. Biochem. J. 2010, 427, 1-17. [CrossRef]

153. Xu, X.; Zhang, M.; Xu, F.; Jiang, S. Wnt signaling in breast cancer: Biological mechanisms, challenges and opportunities. Mol. Cancer 2020, 19, 1-35. [CrossRef]

154. Pohl, S.-G.; Brook, N.; Agostino, M.; Arfuso, F.; Kumar, A.P.; Dharmarajan, A. Wnt signaling in triple-negative breast cancer. Oncogenesis 2017, 6, e310. [CrossRef]

155. Jiang, S.; Zhang, M.; Zhang, Y.; Zhou, W.; Zhu, T.; Ruan, Q.; Chen, H.; Fang, J.; Zhou, F.; Sun, J. WNT5B governs the phenotype of basal-like breast cancer by activating WNT signaling. Cell Commun. Signal. 2019, 17, 1-19. [CrossRef] [PubMed]

156. Dey, N.; Barwick, B.G.; Moreno, C.S.; Ordanic-Kodani, M.; Chen, Z.; Oprea-Ilies, G.; Tang, W.; Catzavelos, C.; Kerstann, K.F.; Sledge, G.W. Wnt signaling in triple negative breast cancer is associated with metastasis. BMC Cancer 2013, 13, 537. [CrossRef] [PubMed]

157. Xu, J.; Prosperi, J.R.; Choudhury, N.; Olopade, O.I.; Goss, K.H. $\beta$-Catenin is required for the tumorigenic behavior of triplenegative breast cancer cells. PLoS ONE 2015, 10, e0117097. [CrossRef]

158. Liu, S.; Wang, Z.; Liu, Z.; Shi, S.; Zhang, Z.; Zhang, J.; Lin, H. miR-221/222 activate the Wnt/ $\beta$-catenin signaling to promote triple-negative breast cancer. J. Mol. Cell Biol. 2018, 10, 302-315. [CrossRef] [PubMed]

159. Dey, N.; Young, B.; Abramovitz, M.; Bouzyk, M.; Barwick, B.; De, P.; Leyland-Jones, B. Differential activation of Wnt- $\beta$-catenin pathway in triple negative breast cancer increases MMP7 in a PTEN dependent manner. PLoS ONE 2013, 8, e77425. [CrossRef] [PubMed]

160. Wu, Y.; Tran, T.; Dwabe, S.; Sarkissyan, M.; Kim, J.; Nava, M.; Clayton, S.; Pietras, R.; Farias-Eisner, R.; Vadgama, J.V. A83-01 inhibits TGF- $\beta$-induced upregulation of Wnt3 and epithelial to mesenchymal transition in HER2-overexpressing breast cancer cells. Breast Cancer Res. Treat. 2017, 163, 449-460. [CrossRef] [PubMed]

161. Khalil, S.; Tan, G.A.; Giri, D.D.; Zhou, X.K.; Howe, L.R. Activation status of Wnt/ss-catenin signaling in normal and neoplastic breast tissues: Relationship to HER2/neu expression in human and mouse. PLoS ONE 2012, 7, e33421. [CrossRef] [PubMed]

162. Wu, Y.; Ginther, C.; Kim, J.; Mosher, N.; Chung, S.; Slamon, D.; Vadgama, J.V. Expression of Wnt3 activates Wnt/ $\beta$-catenin pathway and promotes EMT-like phenotype in trastuzumab-resistant HER2-overexpressing breast cancer cells. Mol. Cancer Res. 2012, 10, 1597-1606. [CrossRef] [PubMed]

163. Prasad, C.P.; Rath, G.; Mathur, S.; Bhatnagar, D.; Ralhan, R. Potent growth suppressive activity of curcumin in human breast cancer cells: Modulation of Wnt/ $\beta$-catenin signaling. Chem. Biol. Interact. 2009, 181, 263-271. [CrossRef]

164. Li, J.; Li, J.; Chen, B. Oct4 was a novel target of Wnt signaling pathway. Mol. Cell. Biochem. 2012, 362, 233-240. [CrossRef]

165. Merrill, B.J. Wnt pathway regulation of embryonic stem cell self-renewal. Cold Spring Harb. Perspect. Biol. 2012,4 , a007971. [CrossRef]

166. Kim, J.-H.; Park, S.-Y.; Jun, Y.; Kim, J.-Y.; Nam, J.-S. Roles of Wnt target genes in the journey of cancer stem cells. Int. J. Mol. Sci. 2017, 18, 1604. [CrossRef] [PubMed]

167. Hu, C.; Li, M.; Guo, T.; Wang, S.; Huang, W.; Yang, K.; Liao, Z.; Wang, J.; Zhang, F.; Wang, H. Anti-metastasis activity of curcumin against breast cancer via the inhibition of stem cell-like properties and EMT. Phytomedicine 2019, 58, 152740. [CrossRef] [PubMed]

168. Li, X.; Wang, X.; Xie, C.; Zhu, J.; Meng, Y.; Chen, Y.; Li, Y.; Jiang, Y.; Yang, X.; Wang, S. Sonic hedgehog and Wnt/ $\beta$-catenin pathways mediate curcumin inhibition of breast cancer stem cells. Anti-Cancer Drugs 2018, 29, 208-215. [CrossRef] [PubMed]

169. An, W.; Lai, H.; Zhang, Y.; Liu, M.; Lin, X.; Cao, S. Apoptotic pathway as the therapeutic target for anticancer traditional chinese medicines. Front. Pharmacol. 2019, 10, 758. [CrossRef]

170. Pfeffer, C.M.; Singh, A.T.K. Apoptosis: A Target for Anticancer Therapy. Int. J. Mol. Sci. 2018, 19, 448. [CrossRef]

171. Singh, R.; Letai, A.; Sarosiek, K. Regulation of apoptosis in health and disease: The balancing act of BCL-2 family proteins. Nat. Rev. Mol. Cell Biol. 2019, 20, 175-193. [CrossRef] [PubMed]

172. Jan, R.; Chaudhry, G.-E.S. Understanding Apoptosis and Apoptotic Pathways Targeted Cancer Therapeutics. Adv. Pharm. Bull. 2019, 9, 205-218. [CrossRef] [PubMed]

173. Nair, P.; Lu, M.; Petersen, S.; Ashkenazi, A. Apoptosis initiation through the cell-extrinsic pathway. Methods Enzymol. 2014, 544, 99-128.

174. Sessler, T.; Healy, S.; Samali, A.; Szegezdi, E. Structural determinants of DISC function: New insights into death receptor-mediated apoptosis signalling. Pharmacol. Ther. 2013, 140, 186-199. [CrossRef]

175. Khandelwal, N.; Simpson, J.; Taylor, G.; Rafique, S.; Whitehouse, A.; Hiscox, J.; Stark, L.A. Nucleolar NF-kB/RelA mediates apoptosis by causing cytoplasmic relocalization of nucleophosmin. Cell Death Differ. 2011, 18, 1889-1903. [CrossRef]

176. Yue, J.; López, J.M. Understanding MAPK Signaling Pathways in Apoptosis. Int. J. Mol. Sci. 2020, 21, 2346. [CrossRef] [PubMed]

177. Khan, M.; Maryam, A.; Qazi, J.I.; Ma, T. Targeting Apoptosis and Multiple Signaling Pathways with Icariside II in Cancer Cells. Int. J. Biol Sci. 2015, 11, 1100-1112. [CrossRef] [PubMed]

178. Fathi, N.; Rashidi, G.; Khodadadi, A.; Shahi, S.; Sharifi, S. STAT3 and apoptosis challenges in cancer. Int. J. Biol Macromol 2018, 117, 993-1001. [CrossRef] 
179. Fong, Y.; Wu, C.-Y.; Chang, K.-F.; Chen, B.-H.; Chou, W.-J.; Tseng, C.-H.; Chen, Y.-C.; Wang, H.-M.D.; Chen, Y.-L.; Chiu, C.-C. Dual roles of extracellular signal-regulated kinase (ERK) in quinoline compound BPIQ-induced apoptosis and anti-migration of human non-small cell lung cancer cells. Cancer Cell Int. 2017, 17, 37. [CrossRef] [PubMed]

180. Xue, M.; Ji, X.; Xue, C.; Liang, H.; Ge, Y.; He, X.; Zhang, L.; Bian, K.; Zhang, L. Caspase-dependent and caspase-independent induction of apoptosis in breast cancer by fucoidan via the PI3K/AKT/GSK3 $\beta$ pathway in vivo and in vitro. Biomed. Pharmacother. 2017, 94, 898-908. [CrossRef]

181. Wong, R.S.Y. Apoptosis in cancer: From pathogenesis to treatment. J. Exp. Clin Cancer Res. 2011, 30, 87. [CrossRef]

182. Pan, S.T.; Li, Z.L.; He, Z.X.; Qiu, J.X.; Zhou, S.F. Molecular mechanisms for tumour resistance to chemotherapy. Clin. Exp. Pharmacol. Physiol. 2016, 43, 723-737. [CrossRef]

183. Lindeman, G.J.; Visvader, J.E. Targeting BCL-2 in breast cancer: Exploiting a tumor lifeline to deliver a mortal blow? Breast Cancer Manag. 2013, 2, 1-4. [CrossRef]

184. Inao, T.; Iida, Y.; Moritani, T.; Okimoto, T.; Tanino, R.; Kotani, H.; Harada, M. Bcl-2 inhibition sensitizes triple-negative human breast cancer cells to doxorubicin. Oncotarget 2018, 9, 25545-25556. [CrossRef]

185. Honma, N.; Horii, R.; Ito, Y.; Saji, S.; Younes, M.; Iwase, T.; Akiyama, F. Differences in clinical importance of Bcl-2 in breast cancer according to hormone receptors status or adjuvant endocrine therapy. BMC Cancer 2015, 15, 698. [CrossRef]

186. Abdel-Fatah, T.; Perry, C.; Dickinson, P.; Ball, G.; Moseley, P.; Madhusudan, S.; Ellis, I.; Chan, S. Bcl2 is an independent prognostic marker of triple negative breast cancer (TNBC) and predicts response to anthracycline combination (ATC) chemotherapy (CT) in adjuvant and neoadjuvant settings. Ann. Oncol. 2013, 24, 2801-2807. [CrossRef]

187. Bouchalova, K.; Kharaishvili, G.; Bouchal, J.; Vrbkova, J.; Megova, M.; Hlobilkova, A. Triple negative breast cancer-BCL2 in prognosis and prediction. Rev. Curr. Drug Targets 2014, 15, 1166-1175. [CrossRef] [PubMed]

188. Yang, X.; Zhong, D.-N.; Qin, H.; Wu, P.-R.; Wei, K.-L.; Chen, G.; He, R.-Q.; Zhong, J.-C. Caspase-3 over-expression is associated with poor overall survival and clinicopathological parameters in breast cancer: A meta-analysis of 3091 cases. Oncotarget 2018, 9, 8629. [CrossRef]

189. Zhou, L.; Li, K.; Luo, Y.; Tian, L.; Wang, M.; Li, C.; Huang, Q. Novel prognostic markers for patients with triple-negative breast cancer. Hum. Pathol. 2013, 44, 2180-2187. [CrossRef] [PubMed]

190. Kamalabadi-Farahani, M.; Najafabadi, M.R.H.; Jabbarpour, Z. Apoptotic Resistance of Metastatic Tumor Cells in Triple Negative Breast Cancer: Roles of Death Receptor-5. Asian Pac. J. Cancer Prev. APJCP 2019, 20, 1743. [CrossRef] [PubMed]

191. Zhang, Y.; Zhang, B. TRAIL resistance of breast cancer cells is associated with constitutive endocytosis of death receptors 4 and 5 . Mol. Cancer Res. 2008, 6, 1861-1871. [CrossRef]

192. Malin, D.; Chen, F.; Schiller, C.; Koblinski, J.; Cryns, V.L. Enhanced metastasis suppression by targeting TRAIL receptor 2 in a murine model of triple-negative breast cancer. Clin. Cancer Res. 2011, 17, 5005-5015. [CrossRef]

193. Schiewer, M.J.; Knudsen, K.E. Transcriptional roles of PARP1 in cancer. Mol. Cancer Res. 2014, 12, 1069-1080. [CrossRef]

194. Morales, J.; Li, L.; Fattah, F.J.; Dong, Y.; Bey, E.A.; Patel, M.; Gao, J.; Boothman, D.A. Review of poly (ADP-ribose) polymerase (PARP) mechanisms of action and rationale for targeting in cancer and other diseases. Crit. Rev. Eukaryot. Gene Exp. 2014, 24, 15-28. [CrossRef]

195. Wang, X.; Zhang, Y.; Zhang, X.; Tian, W.; Feng, W.; Chen, T. The curcumin analogue hydrazinocurcumin exhibits potent suppressive activity on carcinogenicity of breast cancer cells via STAT3 inhibition. Int. J. Oncol. 2012, 40, 1189-1195. [CrossRef]

196. Shen, H.; Shen, J.; Pan, H.; Xu, L.; Sheng, H.; Liu, B.; Yao, M. Curcumin analog B14 has high bioavailability and enhances the effect of anti-breast cancer cells in vitro and in vivo. Cancer Sci. 2021, 112, 815-827. [CrossRef]

197. Lv, Z.-D.; Liu, X.-P.; Zhao, W.-J.; Dong, Q.; Li, F.-N.; Wang, H.-B.; Kong, B. Curcumin induces apoptosis in breast cancer cells and inhibits tumor growth in vitro and in vivo. Int. J. Clin. Exp. Pathol. 2014, 7, 2818.

198. Calaf, G.M.; Ponce-Cusi, R.; Carrión, F. Curcumin and paclitaxel induce cell death in breast cancer cell lines. Oncol. Rep. 2018, 40, 2381-2388. [CrossRef] [PubMed]

199. Sun, S.-H.; Huang, H.-C.; Huang, C.; Lin, J.-K. Cycle arrest and apoptosis in MDA-MB-231/Her2 cells induced by curcumin. Eur. J. Pharmacol. 2012, 690, 22-30. [CrossRef]

200. Rowe, D.L.; Ozbay, T.; O'Regan, R.M.; Nahta, R. Modulation of the BRCA1 protein and induction of apoptosis in triple negative breast cancer cell lines by the polyphenolic compound curcumin. Breast Cancer Basic Clin. Res. 2009, 3, 61-75. [CrossRef]

201. Yang, J.; Cao, Y.; Sun, J.; Zhang, Y. Curcumin reduces the expression of Bcl-2 by upregulating miR-15a and miR-16 in MCF-7 cells. Med. Oncol. 2010, 27, 1114-1118. [CrossRef] [PubMed]

202. Guo, J.; Li, W.; Shi, H.; Xie, X.; Li, L.; Tang, H.; Wu, M.; Kong, Y.; Yang, L.; Gao, J. Synergistic effects of curcumin with emodin against the proliferation and invasion of breast cancer cells through upregulation of miR-34a. Mol. Cell. Biochem. 2013, 382, 103-111. [CrossRef] [PubMed]

203. Moghtaderi, H.; Sepehri, H.; Delphi, L.; Attari, F. Gallic acid and curcumin induce cytotoxicity and apoptosis in human breast cancer cell MDA-MB-231. BioImpacts BI 2018, 8, 185. [CrossRef] [PubMed]

204. Fan, H.; Liang, Y.; Jiang, B.; Li, X.; Xun, H.; Sun, J.; He, W.; Lau, H.T.; Ma, X. Curcumin inhibits intracellular fatty acid synthase and induces apoptosis in human breast cancer MDA-MB-231 cells. Oncol. Rep. 2016, 35, 2651-2656. [CrossRef] [PubMed]

205. Younesian, O.; Kazerouni, F.; Dehghan-Nayeri, N.; Omrani, D.; Rahimipour, A.; Shanaki, M.; Rezapour Kalkhoran, M.; Cheshmi, F. Effect of curcumin on fatty acid synthase expression and enzyme activity in breast cancer cell line SKBR3. Int. J. Cancer Manag. 2017, 10, 1-7. [CrossRef] 
206. Maugeri-Saccà, M.; Barba, M.; Pizzuti, L.; Vici, P.; Di Lauro, L.; Dattilo, R.; Vitale, I.; Bartucci, M.; Mottolese, M.; De Maria, R. The Hippo transducers TAZ and YAP in breast cancer: Oncogenic activities and clinical implications. Exp. Rev. Mol. Med. 2015, 17, e14. [CrossRef] [PubMed]

207. Varelas, X. The Hippo pathway effectors TAZ and YAP in development, homeostasis and disease. Development 2014, 141, 1614-1626. [CrossRef]

208. Shen, Y.; Han, Z.; Liu, S.; Jiao, Y.; Li, Y.; Yuan, H. Curcumin Inhibits the Tumorigenesis of Breast Cancer by Blocking Tafazzin/YesAssociated Protein Axis. Cancer Manag. Res. 2020, 12, 1493-1502. [CrossRef]

209. Yee, N.S. Roles of TRPM8 ion channels in cancer: Proliferation, survival, and invasion. Cancers 2015, 7, 2134-2146. [CrossRef] [PubMed]

210. Urrego, D.; Tomczak, A.P.; Zahed, F.; Stühmer, W.; Pardo, L.A. Potassium channels in cell cycle and cell proliferation. Philos. Trans. R. Soc. B Biol. Sci. 2014, 369, 20130094. [CrossRef]

211. BA Djamgoz, M.; Onkal, R. Persistent current blockers of voltage-gated sodium channels: A clinical opportunity for controlling metastatic disease. Recent Pat. Anti-Cancer Drug Discov. 2013, 8, 66-84. [CrossRef]

212. Bortner, C.D.; Cidlowski, J.A. Ion channels and apoptosis in cancer. Philos. Trans. R. Soc. B Biol. Sci. 2014, $369,20130104$. [CrossRef]

213. Guney Eskiler, G.; Sahin, E.; Deveci Ozkan, A.; Cilingir Kaya, O.T.; Kaleli, S. Curcumin induces DNA damage by mediating homologous recombination mechanism in triple negative breast cancer. Nutr. Cancer 2020, 72, 1057-1066. [CrossRef]

214. Zhou, X.; Jiao, D.; Dou, M.; Zhang, W.; Lv, L.; Chen, J.; Li, L.; Wang, L.; Han, X. Curcumin inhibits the growth of triple-negative breast cancer cells by silencing EZH2 and restoring DLC1 expression. J. Cell. Mol. Med. 2020, 24, 10648-10662. [CrossRef] [PubMed]

215. Rahmah, N.A.; Harliansyah, H.; Suyatna, F.D.; Kanoko, M.; Rustamadji, P.; Prihartono, J.; Haryono, S.J.; Hernowo, B.S. The Role of Curcumin on Apoptosis through The RASSF1A and Bax Pathways in Breast Cancer. Indones. J. Cancer Chemoprev. 2020, 11, 67-74. [CrossRef]

216. Law, J.; Salla, M.; Zare, A.; Wong, Y.; Luong, L.; Volodko, N.; Svystun, O.; Flood, K.; Lim, J.; Sung, M. Modulator of apoptosis 1 (MOAP-1) is a tumor suppressor protein linked to the RASSF1A protein. J. Biol. Chem. 2015, 290, 24100-24118. [CrossRef] [PubMed]

217. Du, L.; Xie, Z.; Wu, L.-c.; Chiu, M.; Lin, J.; Chan, K.K.; Liu, S.; Liu, Z. Reactivation of RASSF1A in breast cancer cells by curcumin. Nutr. Cancer 2012, 64, 1228-1235. [CrossRef]

218. Wang, H.; Zhang, X.; Teng, L.; Legerski, R.J. DNA damage checkpoint recovery and cancer development. Exp. Cell Res. 2015, 334, 350-358. [CrossRef]

219. Ahmad, A.; Wang, Z.; Ali, R.; Bitar, B.; Logna, F.T.; Maitah, M.Y.; Bao, B.; Ali, S.; Kong, D.; Li, Y. Cell cycle regulatory proteins in breast cancer: Molecular determinants of drug resistance and targets for anticancer therapies. Breast Cancer Cells 2012, 113-130. [CrossRef]

220. Ding, L.; Cao, J.; Lin, W.; Chen, H.; Xiong, X.; Ao, H.; Yu, M.; Lin, J.; Cui, Q. The roles of cyclin-dependent kinases in cell-cycle progression and therapeutic strategies in human breast cancer. Int. J. Mol. Sci. 2020, 21, 1960. [CrossRef] [PubMed]

221. Indovina, P.; Pentimalli, F.; Casini, N.; Vocca, I.; Giordano, A. RB1 dual role in proliferation and apoptosis: Cell fate control and implications for cancer therapy. Oncotarget 2015, 6, 17873. [CrossRef]

222. Besson, A.; Dowdy, S.F.; Roberts, J.M. CDK inhibitors: Cell cycle regulators and beyond. Dev. Cell 2008, 14, 159-169. [CrossRef]

223. Bower, J.J.; Vance, L.D.; Psioda, M.; Smith-Roe, S.L.; Simpson, D.A.; Ibrahim, J.G.; Hoadley, K.A.; Perou, C.M.; Kaufmann, W.K. Patterns of cell cycle checkpoint deregulation associated with intrinsic molecular subtypes of human breast cancer cells. NPJ Breast Cancer 2017, 3, 1-12. [CrossRef]

224. Thu, K.; Soria-Bretones, I.; Mak, T.; Cescon, D. Targeting the cell cycle in breast cancer: Towards the next phase. Cell Cycle 2018, 17, 1871-1885. [CrossRef]

225. Mohammadizadeh, F.; Hani, M.; Ranaee, M.; Bagheri, M. Role of cyclin D1 in breast carcinoma. J. Res. Med. Sci. Off. J. Isfahan Univ. Med. Sci. 2013, 18, 1021.

226. Jirawatnotai, S.; Hu, Y.; Michowski, W.; Elias, J.E.; Becks, L.; Bienvenu, F.; Zagozdzon, A.; Goswami, T.; Wang, Y.E.; Clark, A.B. A function for cyclin D1 in DNA repair uncovered by protein interactome analyses in human cancers. Nature 2011, 474, 230-234. [CrossRef] [PubMed]

227. Montalto, F.I.; De Amicis, F. Cyclin D1 in Cancer: A Molecular Connection for Cell Cycle Control, Adhesion and Invasion in Tumor and Stroma. Cells 2020, 9, 2648. [CrossRef] [PubMed]

228. Jirawatnotai, S.; Hu, Y.; Livingston, D.M.; Sicinski, P. Proteomic identification of a direct role for cyclin d1 in DNA damage repair. Cancer Res. 2012, 72, 4289-4293. [CrossRef] [PubMed]

229. Otto, T.; Sicinski, P. Cell cycle proteins as promising targets in cancer therapy. Nat. Rev. Cancer 2017, 17, 93. [CrossRef]

230. Miller, A.H. Phase II Study of Curcumin vs Placebo for Chemotherapy-Treated Breast Cancer Patients Undergoing Radiotherapy. Available online: https:/ / clinicaltrials.gov/ct2/show / record/NCT01740323 (accessed on 3 May 2021).

231. Jurikova, M.; Danihel, L'.; Polák, Š.; Varga, I. Ki67, PCNA, and MCM proteins: Markers of proliferation in the diagnosis of breast cancer. Acta Histochem. 2016, 118, 544-552. [CrossRef] 
232. Bayet-Robert, M.; Kwiatowski, F.; Leheurteur, M.; Gachon, F.; Planchat, E.; Abrial, C.; Mouret-Reynier, M.-A.; Durando, X.; Barthomeuf, C.; Chollet, P. Phase I dose escalation trial of docetaxel plus curcumin in patients with advanced and metastatic breast cancer. Cancer Biol. Ther. 2010, 9, 8-14. [CrossRef]

233. Saghatelyan, T.; Tananyan, A.; Janoyan, N.; Tadevosyan, A.; Petrosyan, H.; Hovhannisyan, A.; Hayrapetyan, L.; Arustamyan, M.; Arnhold, J.; Rotmann, A.-R. Efficacy and safety of curcumin in combination with paclitaxel in patients with advanced, metastatic breast cancer: A comparative, randomized, double-blind, placebo-controlled clinical trial. Phytomedicine 2020, 70, 153218. [CrossRef]

234. Medical University of South Carolina. A “Window Trial” on Curcumin for Invasive Breast Cancer Primary Tumors. Available online: https: / / clinicaltrials.gov / ct2/show / NCT03980509 (accessed on 3 May 2021). 